\title{
Statistical Analysis for Comparison of the Results Obtained by Capillary Columns and Packed Columns in the Determination of Water Yield in Smoke Condensates Analyzed in Cigarettes for the $24^{\text {th }}$ Asia Collaborative Study *
}

\author{
by \\ Hisayuki Takahashi and Masayasu Tanaka \\ Japan Tobacco Inc., 1-17-7 Yokokawa, Sumida-ku, Tokyo, Japan
}

\section{SUMMARY}

Recently, capillary columns have been widely used in the methodology for the determination of water yields in smoke condensate, even though ISO 10362-1:1999, "Cigarettes Determination of water in smoke condensates - Part 1: Gas chromatographic method" specifies a packed gas chromatographic column. As a result of a systematic review in 2015, ISO/TC126 decided to revise the standard to include the use of capillary columns.

The goal of this study was to confirm the comparability of water yields obtained from capillary column methodology to those yields from packed columns by the statistical analysis of yield data from the $24^{\text {th }}$ Asia Collaborative Study which included 86 datasets submitted by 64 laboratories. After the exclusion of outliers by Cochran's and Grubbs' tests, the datasets were classified by GC column type and then mean water yields, and their repeatability and reproducibility were calculated for each type of column. No significant differences were observed in water yields between capillary and packed columns. Repeatability and reproducibility of water yields using capillary column were comparable to those using packed columns as described in ISO 10362-1:1999. From these results, it was confirmed that the capillary columns are an appropriate alternative to packed columns for the gas chromatographic procedure described in ISO 10362-1:1999. [Beitr. Tabakforsch. Int. 29 (2020) 97-118]

\section{ZUSAMMENFASSUNG}

Zur gaschromatographischen Wasserbestimmung im Rauchkondensat von Zigaretten werden immer häufiger Kapillarsäulen verwendet, obwohl in der ISO Norm 10362-1:1999 "Zigaretten -Wasserbestimmung in Rauchkondensaten Teil 1: Gaschromatographisches Verfahren" eine gepackte Trennsäule vorgeschrieben ist. 2015 beschloss ISO/TC 126 auf Basis einer systematischen Überprüfung der einschlägigen Literatur die Verwendung von Kapillarsäulen zur Quantifizierung des Wassers im Rauchkondensat zuzulassen und den Standard den realen Gegebenheiten in den Prüflabors anzupassen.

Ziel dieser Studie war es, die Vergleichbarkeit der gaschromatographisch bestimmten Wasserwerte des Hauptstromrauch-Kondensats von Zigaretten, die mittels gepackter Trennsäulen bzw. Kapillaren erhalten wurden, mithilfe statistischer Verfahren zu bestätigen. Dazu dienten 86 Datensätze aus 64 Laboratorien, die im Rahmen der 24. Asia Collaborative Study erhalten wurden. Nach Ausreißer- 
Bereinigung über Cochran und Grubbs Tests wurden die Datensätze nach den verwendeten Typen der gaschromatographischen Trennkolonnen klassifiziert und die Mittelwerte für den Wassergehalt, deren Wiederholbarkeit und Reproduzierbarkeit für jeden Typ der eingesetzten Trennkolonnen berechnet.

Für die gemessenen quantitativen Wasserwerte zeigten sich keine signifikanten Unterschiede bei Verwendung der Kapillaren oder der gepackten Säulen. Auch die Wiederholbarkeit und Reproduzierbarkeit der mit den Kapillaren erhaltenen Wasserwerte entsprachen den in ISO 10362-1:1999 für gepackte Trennsäulen vorgegebenen. Die von uns erhaltenen Ergebnisse bestätigen, dass Kapillaren eine geeignete Alternative für die gaschromatographischen Wasserbestimmung nach ISO 10362-1:1999 darstellen. [Beitr. Tabakforsch. Int. 29 (2020) 97-118]

\section{RESUME}

Récemment, les colonnes capillaires ont été abondamment utilisées afin de doser méthodiquement les teneurs en eau dans le condensat de fumée même si la norme ISO 10362 1:1999 "Cigarettes - Dosage de l'eau dans les condensats de fumée - Partie 1: Méthode par chromatographie en phase gazeuse" mentionne spécifiquement les colonnes à remplissage pour toute chromatographie gazeuse. A la suite d'un réexamen systématique réalisé en 2015, le comité technique ISO/TC126 décida de revoir la norme afin d'inclure l'utilisation de colonnes capillaires. L'objectif de la présente étude était de confirmer la comparabilité des teneurs en eau relevées par la méthode recourant aux colonnes capillaires à celles mesurées dans les colonnes à remplissage par le biais d'une analyse statistique des données de rendement recensées par la 24 e étude collaborative asiatique qui inclut 86 jeux de données soumis par 64 laboratoires. Après l'exclusion des valeurs aberrantes à travers des tests de Cochran et de Grubbs, les jeux de données furent classés par type de colonne utilisé pour la chromatographie en phase gazeuse et ensuite par teneurs en eau médianes. Ensuite, la répétabilité et la reproductibilité furent calculées pour chaque type de colonne.

Des différences significatives des teneurs en eau ne furent pas observées entre les colonnes capillaires et à remplissage. La répétabilité et la reproductibilité des teneurs en eau mesurées grâce aux colonnes capillaires furent comparables à celles observées sur les colonnes à remplissage prescrites dans la norme ISO 10362-1:1999. A la lumière de ces résultats, il fut confirmé que les colonnes capillaires constituaient une option alternative appropriée aux colonnes à remplissage dans le cadre de la chromatographie en phase gazeuse évoquée dans la norme ISO 10362-1:1999. [Beitr. Tabakforsch. Int. 29 (2020) 97-118]

\section{INTRODUCTION}

The international standard 10362-1:1999 "Cigarette-Determination of water in smoke condensate - Part 1: Gas chromatographic method"'(1) specifies only packed columns in the methodology for water yield analysis even though recently the use of capillary columns for both water and nicotine (2) has become relatively more popular across global laboratories.

Indeed, capillary columns were used in the recently updated CORESTA Recommended Method No 57, "Determination of water in tobacco and tobacco products by gas chromatographic analysis" (3)

Based on this situation, ISO/TC 126 decided in 2015 to create a Working Group 17 (WG 17) to revise ISO10362-1:1999 to include capillary columns as one of the methodology options, starting with discussion and a systematic review. At the first ISO/TC 126/WG 17 meeting, the necessity for a comparison of water yields using either packed or capillary columns in the methodology, was identified.

Yield data were gathered and analysed from several collaborative studies e.g., of $24^{\text {th }}$ Asia Collaborative Study 2015 (ACS, the meeting was held in Bali in 2016), of the European Collaborative Study 2016 (EUCS, organized by the Committee on Tobacco and Tobacco Smoke of the German Institute for Standardization (DIN)) and of the CORESTA CM8 collaborative study 2017 (4). Water yield comparability was presented and confirmed in all collaborative studies at the WG17 meeting held in November 2017. The results from the monitor cigarette (CM8) from the CORESTA collaborative study were published by CRUMPLER et al. (4), but only one brand for test samples was used.

On the other hand, ACS 2015 and EUCS 2016 used five different brands for test samples. Although the results of EUCS didn't contain datasets obtained with the combination of packed columns and linear smoking machines, the results of ACS (5) contained datasets obtained with all combinations of GC columns and smoking machines. Consequently, WG17 decided to use the results of ACS for the revision of the international standard.

This paper has been written to provide a comprehensive statistical comparison in terms of water yield differences between packed and capillary columns obtained from the $24^{\text {th }}$ Asia Collaborative Study (2015) covering cigarettes across a typical range of "tar" yields.

\section{EXPERIMENTAL}

\section{Asia Collaborative Study - Participants}

64 laboratories participated in the $24^{\text {th }}$ Asia Collaborative Study (ACS) held in 2015. All participating laboratories are listed in Table A of Appendix A. The laboratories marked with an asterisk provided more than one dataset which were obtained by using various combinations of linear and rotary smoking machines.

In this study, 86 datasets were submitted with their water yields analysed. They consisted of 46 datasets measured by capillary column, 39 datasets measured by packed column, and 1 dataset without mention which column was used.

\section{Protocol}

Participants were requested to follow the protocol "ACS" to analyse five test samples, including CORESTA Monitor CM8 (6) as listed in Table 1, and to report on parameters as listed in Tables 2 and 3. 
Table 1. List of samples.

\begin{tabular}{c|cccccc}
\hline Code & Sample name & Supplier & Origin & $\begin{array}{c}\text { NFDPM } \\
\text { level } \\
(\mathrm{mg} / \mathrm{cig})\end{array}$ & $\begin{array}{c}\text { Butt } \\
\text { length } \\
(\mathrm{mm})\end{array}$ \\
\hline A & Mevius One Box & JT & Japan & 1 & 35 \\
B & Marlboro Clear 3 Box & PMI & Lithuania & 3 & 35 \\
C & Kent 6 KS Box & RJR & USA & 6 & 35 \\
D & Mevius Box & JT & Japan & 10 & 35 \\
E & CORESTA Monitor & COR & Germany & $14.1^{*}$ & 33 \\
\hline
\end{tabular}

Suppliers: JT: Japan Tobacco Inc., PMI: Philip Morris International, RJR: R J Reynolds, COR: CORESTA

CM8 was provided by Cerulean in this year.

* NFDPM was quoted from 'CORESTA Approved Monitor No.8 (CM8) use of condition, June 2015' (6).

Table 2. List of parameters to be reported.

\begin{tabular}{|c|c|}
\hline & Outline \\
\hline Test period & September $1^{\text {st }}$ to November $30^{\text {th }}, 2015$ \\
\hline $\begin{array}{l}\text { Data set / } \\
\text { sample }\end{array}$ & $\begin{array}{l}\text { One data set consists of } 6 \text { test results obtained from } \\
6 \text { runs. One test result was defined as the average } \\
\text { yield obtained from } 20 \text { cigarettes in a single run. }\end{array}$ \\
\hline $\begin{array}{l}\text { Test } \\
\text { parameters }\end{array}$ & TPM, water, nicotine, NFDPM, CO, puffs \\
\hline $\begin{array}{l}\text { Original } \\
\text { data sets }\end{array}$ & 86 data sets from 64 laboratories for each sample \\
\hline
\end{tabular}

Table 3. Dataset per sample.

\begin{tabular}{l|c|c|c}
\hline Test parameter & $\begin{array}{c}\text { Smoking } \\
\text { machine }\end{array}$ & $\begin{array}{c}\text { Number of } \\
\text { runs }\end{array}$ & $\begin{array}{c}\text { Reported data / } \\
\text { sample }\end{array}$ \\
\hline $\begin{array}{l}\text { TPM (mg/cig) } \\
\text { Water (mg/cig) }\end{array}$ & $\begin{array}{c}\text { Linear } 20 \\
\text { port }\end{array}$ & $\begin{array}{c}6 \text { runs } \\
\text { Nicotine (mg/cig) }\end{array}$ & $\begin{array}{c}6 \text { test results, } \\
\text { mean and } \\
\text { standard } \\
\text { deviation }\end{array}$ \\
NFDPM (mg/cig) & $\begin{array}{c}\text { Linear } 16 \\
\text { port } \\
\text { Linear } 10 \\
\text { port }\end{array}$ & $\begin{array}{c}4 \text { ports/run } \\
\text { CO (mg/cig) }\end{array}$ & $\begin{array}{c}6 \text { runs } \\
(20 \text { cig/run })\end{array}$ \\
Puff count (puffs/cig) & Rotary & \\
\hline
\end{tabular}

As shown in Table 1, the four sample brands covered the range in NFDPM from 1 to $10 \mathrm{mg} / \mathrm{cig}$, NFDPM of CM8 was reported to be $14.1 \mathrm{mg} / \mathrm{cig}$ (6). CORESTA Monitor CM8 was provided by Cerulean or Borgwaldt KC year by year in turn and Cerulean provided it in that particular year.

One dataset consists of six test results obtained from six runs, as shown in Table 2. One test result was defined as the average yield obtained from 20 cigarettes in a single run. For linear smoking machines, four ports per brand were used within each run, and five cigarettes were smoked per port. Rotary smoking machine always used 20 cigarettes per run.

\section{Raw data}

Raw datasets are listed in APPENDIX B with the type of smoking machine and GC column, water yields for each run, mean and standard deviation (SD) for five test samples.

\section{Statistical analysis - Exclusion of outliers}

Numerical outlier technique: Cochran's and Grubbs' tests were applied in accordance with ISO 5725-2:1994 (7) to exclude outlying datasets prior to the determination of repeatability and reproducibility. Cochran's test was applied to identify an outlier with statistically deviant standard deviation. Grubbs' test was applied to identify an outlier in a univariate dataset that follows an approximately normal distribution.

After Cochran's test, Grubbs' test was applied to the mean values of the remaining datasets according to chapter 7.3.4.3 in ISO5725-2 (7). Grubbs' test consists of two types of tests. One is to determine whether the largest or smallest observation is the outlier, this is called the single Grubbs' test (chapter 7.3.4.1 in ISO 5725-2). The second test is to determine whether the two largest observations or two smallest observations are the outliers, it is called the double Grubbs' test (chapter 7.3.4.2 in ISO 5725-2).

In the first step, the datasets were sorted in descending order for mean value. The Grubbs' statistics $G p$ was calculated using the maximum mean value $x p$, ground mean and standard deviation $s$. Where the Grubbs' statistics was higher than $1 \%$ of critical value (8), the maximum value was considered as outlier. The same process was applied for the dataset with the minimum mean value. When outliers are determined by single Grubbs' test, the Grubbs' test is completed. If there is no outlier in single Grubbs' test, double Grubbs' test for the two smallest or two largest observations should be applied.

\section{Repeatability and reproducibility estimation}

Water yield repeatability (r) and reproducibility (R) were calculated for all types of gas chromatographic columns and each type of GC column seperately, with all types of smoking machines according to ISO 5725-2:1994 (7), by using the data that remained after the removal of outliers.

\section{RESULTS}

\section{Statistical analysis}

\section{Mean and standard deviation}

Mean and standard deviation for each dataset were calculated and are listed in Table 4.

The labcode was randomly assigned and is in no way related to the participation numbers of the laboratories, which were given in numerical order of data submission.

\section{Exclusion of outliers}

85 datasets, shown in Table 4, were sorted in descending order of their standard deviation. The test statistic $C$ was calculated and compared with $1 \%$ of critical value. Cochran's critical values are given in ISO 5725-2 (7) only up to 40 numbers of data sets.

As the numbers of datasets exceeded 40 in this study, Cochran's critical value at corresponding numbers of datasets were calculated by use of the approximation in (9) which 
Table 4. Mean and standard deviation (SD) of water yields for each data set (unit: $\mathrm{mg} / \mathrm{cig}$ ).

\begin{tabular}{|c|c|c|c|c|c|c|c|c|c|c|c|c|c|}
\hline \multirow{2}{*}{ No. } & \multirow{2}{*}{$\begin{array}{l}\text { Smoking } \\
\text { machine }\end{array}$} & \multirow{2}{*}{$\begin{array}{c}\mathrm{GC} \\
\text { column }^{\mathrm{b}}\end{array}$} & \multirow{2}{*}{$\begin{array}{l}\text { Lab. } \\
\text { code }\end{array}$} & \multicolumn{2}{|c|}{ Sample A } & \multicolumn{2}{|c|}{ Sample B } & \multicolumn{2}{|c|}{ Sample C } & \multicolumn{2}{|c|}{ Sample D } & \multicolumn{2}{|c|}{ Sample E } \\
\hline & & & & Mean & SD & Mean & SD & Mean & SD & Mean & $\mathrm{SD}$ & Mean & SD \\
\hline 1 & $\mathrm{R}$ & $\mathrm{C}$ & 01R & 0.07 & 0.031 & 0.14 & 0.037 & 0.96 & 0.103 & 1.69 & 0.086 & 1.90 & 0.109 \\
\hline 2 & $\mathrm{R}$ & $\mathrm{C}$ & $02 \mathrm{R}$ & 0.09 & 0.061 & 0.30 & 0.084 & 1.01 & 0.154 & 1.93 & 0.207 & 2.23 & 0.172 \\
\hline 3 & $\mathrm{~L}$ & $\mathrm{P}$ & $03 \mathrm{AL}$ & 0.08 & 0.066 & 0.17 & 0.053 & 0.45 & 0.046 & 1.03 & 0.053 & 1.21 & 0.052 \\
\hline 4 & $\mathrm{R}$ & $\mathrm{P}$ & 03BR & 0.07 & 0.052 & 0.15 & 0.031 & 0.55 & 0.111 & 1.22 & 0.167 & 1.34 & 0.182 \\
\hline 5 & $\mathrm{~L}$ & $\mathrm{P}$ & 04L & 0.15 & 0.024 & 0.33 & 0.046 & 0.69 & 0.065 & 1.34 & 0.078 & 1.56 & 0.121 \\
\hline 6 & L & $\mathrm{P}$ & $05 \mathrm{~L}$ & 0.10 & 0.029 & 0.29 & 0.042 & 0.68 & 0.057 & 1.54 & 0.076 & 1.72 & 0.092 \\
\hline 7 & L & $\mathrm{C}$ & 06AL & 0.09 & 0.030 & 0.38 & 0.176 & 0.61 & 0.121 & 1.38 & 0.228 & 1.62 & 0.393 \\
\hline 8 & $\mathrm{~L}$ & $\mathrm{C}$ & 06BL & 0.20 & 0.104 & 0.35 & 0.237 & 0.55 & 0.180 & 1.00 & 0.216 & 1.50 & 0.481 \\
\hline 9 & $\mathrm{R}$ & C & 07AR & 0.12 & 0.035 & 0.43 & 0.056 & 0.96 & 0.048 & 1.90 & 0.097 & 2.16 & 0.132 \\
\hline 10 & $\mathrm{R}$ & C & 07BR & 0.10 & 0.036 & 0.35 & 0.039 & 0.92 & 0.036 & 1.83 & 0.116 & 2.17 & 0.033 \\
\hline 11 & $\mathrm{~L}$ & $C$ & $07 \mathrm{CL}$ & 0.07 & 0.022 & 0.19 & 0.042 & 0.58 & 0.017 & 1.23 & 0.151 & 1.43 & 0.050 \\
\hline 12 & $\mathrm{R}$ & $C$ & 08R & 0.09 & 0.041 & 0.27 & 0.042 & 0.87 & 0.056 & 1.69 & 0.089 & 1.97 & 0.115 \\
\hline 13 & $\mathrm{R}$ & C & 09R & 0.08 & 0.080 & 0.23 & 0.041 & 0.80 & 0.118 & 1.55 & 0.107 & 1.90 & 0.090 \\
\hline 14 & $\mathrm{R}$ & C & $10 \mathrm{R}$ & 0.04 & 0.023 & 0.26 & 0.021 & 0.86 & 0.051 & 2.02 & 0.049 & 2.14 & 0.080 \\
\hline 15 & $\mathrm{~L}$ & $C$ & $11 \mathrm{~L}$ & 0.06 & 0.043 & 0.21 & 0.043 & 0.49 & 0.131 & 1.21 & 0.130 & 1.32 & 0.074 \\
\hline 16 & $\mathrm{R}$ & $P$ & $12 \mathrm{R}$ & 0.08 & 0.023 & 0.31 & 0.068 & 1.05 & 0.085 & 1.72 & 0.033 & 2.19 & 0.126 \\
\hline 17 & $\mathrm{R}$ & C & 13AR & 0.13 & 0.037 & 0.29 & 0.038 & 0.93 & 0.012 & 1.45 & 0.115 & 1.52 & 0.115 \\
\hline 18 & $\mathrm{R}$ & C & 13BR & 0.13 & 0.017 & 0.34 & 0.079 & 0.88 & 0.053 & 1.54 & 0.095 & 1.68 & 0.170 \\
\hline 19 & $\mathrm{R}$ & $\mathrm{P}$ & $14 \mathrm{R}$ & 0.17 & 0.017 & 0.37 & 0.071 & 0.86 & 0.088 & 1.67 & 0.179 & 1.90 & 0.096 \\
\hline 20 & $\mathrm{R}$ & $C$ & 15AR & 0.14 & 0.053 & 0.32 & 0.042 & 0.97 & 0.055 & 1.69 & 0.037 & 1.92 & 0.066 \\
\hline 21 & $\mathrm{~L}$ & C & $15 B L$ & 0.13 & 0.085 & 0.17 & 0.100 & 0.51 & 0.113 & 1.13 & 0.138 & 1.52 & 0.215 \\
\hline 22 & $\mathrm{R}$ & $P$ & $16 \mathrm{R}$ & 0.08 & 0.059 & 0.27 & 0.105 & 0.74 & 0.134 & 1.54 & 0.113 & 1.70 & 0.148 \\
\hline 23 & $\mathrm{R}$ & $P$ & $17 \mathrm{AR}$ & 0.09 & 0.015 & 0.27 & 0.031 & 0.77 & 0.103 & 1.52 & 0.145 & 1.82 & 0.112 \\
\hline 24 & $\mathrm{~L}$ & $P$ & $17 \mathrm{BL}$ & 0.10 & 0.022 & 0.21 & 0.034 & 0.53 & 0.072 & 1.15 & 0.141 & 1.31 & 0.076 \\
\hline 25 & $\mathrm{R}$ & C & 18AR & 0.10 & 0.004 & 0.35 & 0.034 & 0.88 & 0.078 & 1.63 & 0.096 & 1.78 & 0.145 \\
\hline 26 & $\mathrm{~L}$ & C & $18 \mathrm{BL}$ & 0.09 & 0.019 & 0.30 & 0.056 & 0.66 & 0.158 & 1.45 & 0.184 & 1.39 & 0.203 \\
\hline 27 & $\mathrm{~L}$ & C & $19 A L$ & 0.06 & 0.017 & 0.25 & 0.013 & 0.62 & 0.044 & 1.47 & 0.078 & 1.63 & 0.089 \\
\hline 28 & $\mathrm{R}$ & $C$ & 19BR & 0.13 & 0.038 & 0.28 & 0.039 & 0.90 & 0.061 & 1.69 & 0.073 & 2.03 & 0.066 \\
\hline 29 & $\mathrm{~L}$ & C & $19 \mathrm{CL}$ & 0.08 & 0.014 & 0.27 & 0.018 & 0.67 & 0.024 & 1.47 & 0.085 & 1.73 & 0.112 \\
\hline 30 & $\mathrm{R}$ & C & 19DR & 0.08 & 0.061 & 0.25 & 0.054 & 0.82 & 0.078 & 1.47 & 0.083 & 1.82 & 0.033 \\
\hline 31 & $\mathrm{~L}$ & $P$ & 19EL & 0.06 & 0.013 & 0.22 & 0.010 & 0.55 & 0.033 & 1.36 & 0.029 & 1.44 & 0.040 \\
\hline 32 & L & $P$ & $20 \mathrm{~L}$ & 0.06 & 0.014 & 0.27 & 0.039 & 0.63 & 0.073 & 1.45 & 0.058 & 1.62 & 0.054 \\
\hline 33 & $L$ & $C$ & $21 \mathrm{~L}$ & 0.13 & 0.004 & 0.26 & 0.012 & 0.77 & 0.012 & 1.45 & 0.010 & 1.84 & 0.039 \\
\hline 34 & $\mathrm{R}$ & C & $22 \mathrm{R}$ & 0.11 & 0.083 & 0.29 & 0.061 & 0.87 & 0.156 & 1.80 & 0.197 & 2.06 & 0.101 \\
\hline 35 & $\mathrm{R}$ & C & $23 R$ & 0.00 & 0.005 & 0.24 & 0.076 & 0.80 & 0.125 & 1.46 & 0.072 & 1.80 & 0.052 \\
\hline 36 & $\mathrm{R}$ & $C$ & 24AR & 0.11 & 0.005 & 0.23 & 0.017 & 0.73 & 0.014 & 1.43 & 0.119 & 1.79 & 0.088 \\
\hline 37 & $\mathrm{~L}$ & $\mathrm{C}$ & $24 \mathrm{BL}$ & 0.12 & 0.008 & 0.33 & 0.009 & 0.64 & 0.016 & 1.38 & 0.128 & 1.66 & 0.050 \\
\hline 38 & $\mathrm{R}$ & $P$ & $25 \mathrm{R}$ & 0.10 & 0.014 & 0.37 & 0.043 & 1.03 & 0.116 & 1.94 & 0.170 & 2.20 & 0.213 \\
\hline 39 & $\mathrm{R}$ & $\mathrm{C}$ & 26AR & 0.14 & 0.051 & 0.31 & 0.066 & 0.91 & 0.045 & 1.92 & 0.227 & 2.13 & 0.137 \\
\hline 40 & $\mathrm{R}$ & $\mathrm{C}$ & 26BR & 0.14 & 0.052 & 0.38 & 0.044 & 1.07 & 0.063 & 2.03 & 0.130 & 2.33 & 0.077 \\
\hline 41 & $\mathrm{~L}$ & C & $27 \mathrm{~L}$ & 0.09 & 0.105 & 0.19 & 0.082 & 0.57 & 0.088 & 1.21 & 0.177 & 1.35 & 0.108 \\
\hline 42 & $\mathrm{~L}$ & $P$ & $28 \mathrm{~L}$ & 0.21 & 0.078 & 0.33 & 0.103 & 0.70 & 0.119 & 1.55 & 0.154 & 1.87 & 0.167 \\
\hline 43 & $\mathrm{~L}$ & $P$ & $29 \mathrm{~L}$ & - & - & 0.27 & 0.104 & 0.70 & 0.073 & 1.41 & 0.262 & 1.60 & 0.212 \\
\hline 44 & $\mathrm{R}$ & $P$ & $30 \mathrm{R}$ & 0.09 & 0.022 & 0.35 & 0.064 & 1.03 & 0.077 & 2.03 & 0.121 & 2.10 & 0.105 \\
\hline 45 & $\mathrm{~L}$ & $P$ & $31 \mathrm{~L}$ & 0.08 & 0.053 & 0.40 & 0.345 & 0.55 & 0.213 & 1.33 & 0.202 & 1.53 & 0.236 \\
\hline 46 & $\mathrm{R}$ & $C$ & $32 \mathrm{AR}$ & 0.06 & 0.031 & 0.20 & 0.093 & 0.81 & 0.102 & 1.61 & 0.083 & 1.88 & 0.075 \\
\hline 47 & $\mathrm{R}$ & C & 32BR & 0.07 & 0.041 & 0.29 & 0.106 & 0.88 & 0.138 & 1.73 & 0.120 & 1.95 & 0.161 \\
\hline 48 & $\mathrm{R}$ & C & $33 R$ & 0.05 & 0.011 & 0.24 & 0.041 & 0.70 & 0.085 & 1.36 & 0.155 & 1.58 & 0.110 \\
\hline 49 & $\mathrm{R}$ & $P$ & $34 \mathrm{R}$ & 0.16 & 0.072 & 0.39 & 0.084 & 1.21 & 0.134 & 2.26 & 0.244 & 2.57 & 0.321 \\
\hline 50 & $\mathrm{~L}$ & $P$ & $35 \mathrm{~L}$ & 0.11 & 0.092 & 0.62 & 0.371 & 0.84 & 0.234 & 1.75 & 0.261 & 2.21 & 0.219 \\
\hline 51 & $\mathrm{R}$ & C & $36 \mathrm{AR}$ & 0.17 & 0.015 & 0.52 & 0.030 & 0.89 & 0.056 & 1.37 & 0.053 & 2.30 & 0.060 \\
\hline 52 & $\mathrm{R}$ & C & 36BR & 0.19 & 0.034 & 0.52 & 0.025 & 0.94 & 0.036 & 1.46 & 0.069 & 2.43 & 0.051 \\
\hline 53 & $\mathrm{R}$ & $\mathrm{C}$ & $37 \mathrm{AR}$ & 0.08 & 0.084 & 0.20 & 0.098 & 0.70 & 0.183 & 1.53 & 0.231 & 1.78 & 0.341 \\
\hline 54 & $\mathrm{~L}$ & $C$ & $37 \mathrm{BL}$ & 0.11 & 0.087 & 0.42 & 0.181 & 0.85 & 0.171 & 1.31 & 0.178 & 1.70 & 0.152 \\
\hline 55 & $\mathrm{R}$ & $P$ & $38 \mathrm{R}$ & 0.14 & 0.071 & 0.28 & 0.024 & 0.86 & 0.060 & 1.73 & 0.100 & 1.88 & 0.073 \\
\hline 56 & $\mathrm{R}$ & $P$ & $39 R$ & 0.13 & 0.048 & 0.35 & 0.069 & 1.03 & 0.150 & 1.91 & 0.203 & 2.01 & 0.518 \\
\hline 57 & $\mathrm{R}$ & $\mathrm{P}$ & $40 \mathrm{R}$ & 0.14 & 0.084 & 0.37 & 0.076 & 1.30 & 0.329 & 2.44 & 0.287 & 2.70 & 0.219 \\
\hline 58 & $\mathrm{R}$ & C & $41 R$ & 0.11 & 0.031 & 0.25 & 0.010 & 0.83 & 0.100 & 1.42 & 0.117 & 1.78 & 0.106 \\
\hline
\end{tabular}


Table 4. Continued.

\begin{tabular}{|c|c|c|c|c|c|c|c|c|c|c|c|c|c|}
\hline \multirow{2}{*}{ No. } & \multirow{2}{*}{$\begin{array}{l}\text { Smoking } \\
\text { machine }\end{array}$} & \multirow{2}{*}{$\begin{array}{c}\mathrm{GC} \\
\text { column }\end{array}$} & \multirow{2}{*}{$\begin{array}{l}\text { Lab. } \\
\text { code }\end{array}$} & \multicolumn{2}{|c|}{ Sample A } & \multicolumn{2}{|c|}{ Sample B } & \multicolumn{2}{|c|}{ Sample C } & \multicolumn{2}{|c|}{ Sample D } & \multicolumn{2}{|c|}{ Sample E } \\
\hline & & & & Mean & SD & Mean & SD & Mean & SD & Mean & SD & Mean & SD \\
\hline 59 & $\mathrm{~L}$ & $\mathrm{C}$ & $42 \mathrm{~L}$ & 0.10 & 0.017 & 0.26 & 0.044 & 0.57 & 0.052 & 1.19 & 0.040 & 1.52 & 0.104 \\
\hline 60 & $\mathrm{~L}$ & $\mathrm{P}$ & $43 A L$ & 0.21 & 0.057 & 0.44 & 0.112 & 0.75 & 0.032 & 1.36 & 0.072 & 1.63 & 0.136 \\
\hline 61 & $\mathrm{~L}$ & $\mathrm{P}$ & 43BL & 0.20 & 0.014 & 0.47 & 0.178 & 0.73 & 0.015 & 1.35 & 0.064 & 1.58 & 0.069 \\
\hline 62 & $\mathrm{~L}$ & $\mathrm{C}$ & $44 \mathrm{AL}$ & 0.11 & 0.105 & 0.27 & 0.186 & 0.55 & 0.150 & 1.29 & 0.151 & 1.66 & 0.129 \\
\hline 63 & $\mathrm{~L}$ & C & 44BL & 0.07 & 0.108 & 0.22 & 0.035 & 0.61 & 0.138 & 1.35 & 0.186 & 1.58 & 0.156 \\
\hline 64 & $\mathrm{R}$ & $P$ & $45 R$ & 0.06 & 0.026 & 0.23 & 0.032 & 0.70 & 0.074 & 1.58 & 0.168 & 1.71 & 0.073 \\
\hline 65 & $\mathrm{~L}$ & $\mathrm{P}$ & $46 \mathrm{~L}$ & 0.03 & 0.054 & 0.14 & 0.108 & 0.50 & 0.087 & 1.03 & 0.126 & 1.01 & 0.079 \\
\hline 66 & $\mathrm{~L}$ & $P$ & $47 \mathrm{~L}$ & 0.19 & 0.072 & 0.42 & 0.125 & 0.78 & 0.099 & 1.55 & 0.172 & 1.70 & 0.259 \\
\hline 67 & $\mathrm{~L}$ & $C$ & $48 \mathrm{~L}$ & 0.10 & 0.004 & 0.30 & 0.010 & 0.77 & 0.018 & 1.30 & 0.037 & 1.78 & 0.028 \\
\hline 68 & $\mathrm{R}$ & $P$ & $49 R$ & 0.21 & 0.071 & 0.33 & 0.117 & 1.05 & 0.104 & 1.85 & 0.108 & 1.94 & 0.129 \\
\hline 69 & $\mathrm{R}$ & $P$ & 50AR & 0.07 & 0.054 & 0.23 & 0.040 & 0.77 & 0.034 & 1.63 & 0.128 & 1.83 & 0.113 \\
\hline 70 & $\mathrm{R}$ & $P$ & 50BR & 0.04 & 0.031 & 0.19 & 0.039 & 0.75 & 0.084 & 1.65 & 0.083 & 1.85 & 0.047 \\
\hline 71 & $\mathrm{~L}$ & $P$ & $50 \mathrm{CL}$ & 0.09 & 0.045 & 0.25 & 0.081 & 0.56 & 0.074 & 1.38 & 0.098 & 1.46 & 0.127 \\
\hline 72 & $\mathrm{R}$ & $C$ & $51 \mathrm{R}$ & 0.11 & 0.023 & 0.40 & 0.053 & 0.98 & 0.121 & 1.95 & 0.122 & 2.19 & 0.160 \\
\hline 73 & $\mathrm{R}$ & C & $52 R$ & 0.00 & 0.000 & 0.05 & 0.062 & 0.64 & 0.123 & 1.79 & 0.167 & 2.18 & 0.192 \\
\hline 74 & $L$ & $P$ & $53 \mathrm{~L}$ & 0.06 & 0.015 & 0.26 & 0.025 & 0.75 & 0.010 & 1.60 & 0.070 & 1.69 & 0.047 \\
\hline 75 & $\mathrm{R}$ & $C$ & $54 \mathrm{R}$ & 0.09 & 0.021 & 0.25 & 0.026 & 0.81 & 0.091 & 1.50 & 0.090 & 1.85 & 0.064 \\
\hline 76 & $\mathrm{R}$ & UN & $55 \mathrm{R}$ & 0.44 & 0.150 & 0.41 & 0.139 & 0.94 & 0.120 & 1.25 & 0.192 & 1.97 & 0.195 \\
\hline 77 & $\mathrm{~L}$ & $\mathrm{P}$ & $56 \mathrm{~L}$ & 1.43 & 0.368 & 1.84 & 0.713 & 2.47 & 0.936 & 3.82 & 1.050 & 4.33 & 1.388 \\
\hline 78 & $\mathrm{R}$ & $P$ & $57 R$ & 0.13 & 0.023 & 0.35 & 0.053 & 0.97 & 0.045 & 1.99 & 0.104 & 2.26 & 0.088 \\
\hline 79 & $\mathrm{~L}$ & $P$ & $58 \mathrm{~L}$ & 0.07 & 0.028 & 0.23 & 0.091 & 0.52 & 0.051 & 1.22 & 0.112 & 1.50 & 0.113 \\
\hline 80 & $L$ & $\mathrm{P}$ & $59 \mathrm{~L}$ & 0.72 & 0.607 & 1.00 & 0.660 & 1.24 & 0.637 & 1.79 & 0.493 & 3.27 & 0.758 \\
\hline 81 & $\mathrm{R}$ & $P$ & 60AR & 0.07 & 0.015 & 0.30 & 0.039 & 0.85 & 0.099 & 1.58 & 0.085 & 2.17 & 0.127 \\
\hline 82 & $\mathrm{~L}$ & $P$ & $60 \mathrm{BL}$ & 0.07 & 0.021 & 0.27 & 0.046 & 0.66 & 0.079 & 1.61 & 0.114 & 2.41 & 0.243 \\
\hline 83 & $\mathrm{R}$ & $P$ & $61 R$ & 0.13 & 0.008 & 0.30 & 0.024 & 0.71 & 0.016 & 1.01 & 0.016 & 1.90 & 0.012 \\
\hline 84 & $\mathrm{R}$ & $C$ & $62 \mathrm{R}$ & 0.04 & 0.043 & 0.31 & 0.134 & 1.04 & 0.162 & 2.26 & 0.288 & 2.35 & 0.326 \\
\hline 85 & $L$ & $C$ & $63 \mathrm{~L}$ & 0.18 & 0.008 & 0.34 & 0.015 & 0.73 & 0.035 & 1.24 & 0.015 & 1.69 & 0.041 \\
\hline 86 & $\mathrm{R}$ & $P$ & $64 \mathrm{R}$ & 0.04 & 0.015 & 0.22 & 0.073 & 0.59 & 0.102 & 1.41 & 0.162 & 1.43 & 0.170 \\
\hline
\end{tabular}

a Smoking machine R: rotary smoking machine, L: linear smoking machine

${ }^{b}$ GC column C: capillary column, P: packed column, UN: unknown

Table 5. Results of outlier tests.

\begin{tabular}{l|c|c|c}
\hline Sample & Cochran's test & Grubbs' test & $\begin{array}{c}\text { Remaining } \\
\text { data sets }\end{array}$ \\
\hline A & 59 L, 56 L, 55 R & N/A & 82 \\
B & 56 L, 59 L, 35 L & N/A & 82 \\
C & 56 L, 59 L, 40 R & N/A & 82 \\
D & 56 L, 59 L & N/A & 83 \\
E & 56 L, 59 L, 39 R & N/A & 82 \\
\hline
\end{tabular}

N/A: Not applicable

extends the Cochran's test beyond 40 data sets.

When the test statistics was higher than the critical value, the dataset was considered an outlier. After the exclusion of an outlier dataset, the test statistic $C$ for the next dataset with a higher standard deviation was calculated and compared to the critical value. Prior to the analysis the maximum number of outlier tests was restricted to four to avoid an excessive exclusion of dataset. The results of Cochran's test are listed in Table 5. Applying Cochran's test, two or three datasets were excluded as outliers. Grubbs' test was applied for the mean values of the remaining datasets. There was no outlier in Grubbs' test. The excluded datasets determined by Cochran's test and Grubbs' test are listed in Table 5.
Table 6. Number of datasets classified by GC column type and smoking machine type.

\begin{tabular}{ccccccc}
\hline $\begin{array}{c}\text { Sample } \\
\text { code }\end{array}$ & $\begin{array}{c}\text { Total } \\
\text { datasets }\end{array}$ & $\begin{array}{c}\text { Column } \\
\text { type }\end{array}$ & $\begin{array}{c}\text { Total by } \\
\text { GC column }\end{array}$ & $\begin{array}{c}\text { Linear } \\
\text { smoking }\end{array}$ & $\begin{array}{c}\text { Rotary } \\
\text { smoking }\end{array}$ \\
\hline \multirow{3}{*}{ A } & \multirow{5}{*}{$\begin{array}{c}\text { Capillary } \\
\text { s }\end{array}$} & 46 & 17 & 29 \\
& & Packed & 36 & 17 & 19 \\
B & 82 & Capillary & 46 & 17 & 29 \\
& & Packed & 36 & 17 & 19 \\
C & \multirow{2}{*}{82} & Capillary & 46 & 17 & 29 \\
& & Packed & 36 & 18 & 18 \\
D & \multirow{2}{*}{83} & Capillary & 46 & 17 & 29 \\
& & Packed & 37 & 18 & 19 \\
E & \multirow{2}{*}{82} & Capillary & 46 & 17 & 29 \\
& & Packed & 36 & 18 & 18 \\
\hline
\end{tabular}

Two or three datasets from a total of 85 datasets were excluded from further statistical evaluation. The number of datasets classified by GC column type and smoking machine type is listed in Table 6 .

\section{Comparison of capillary column with packed column}

Datasets were classified by GC column type into capillary data and packed column data. Box plots of each column type for each test sample are shown in Figures 1 to 5. 


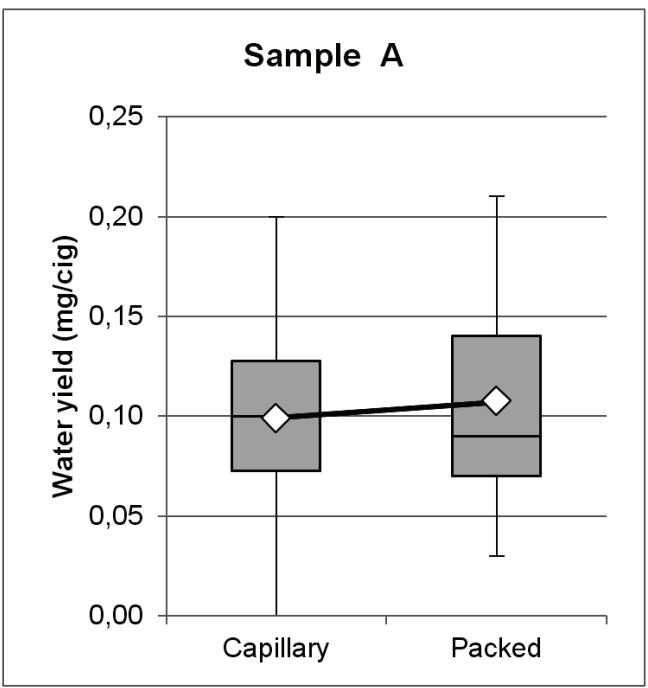

Figure 1. Box plots of water yield for sample A. $\diamond$ indicate mean values

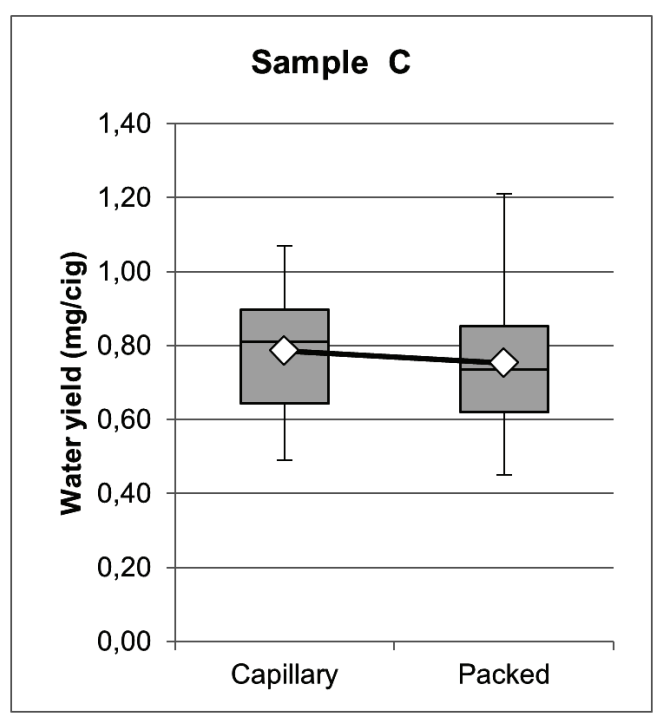

Figure 3. Box plots of water yield for sample C.

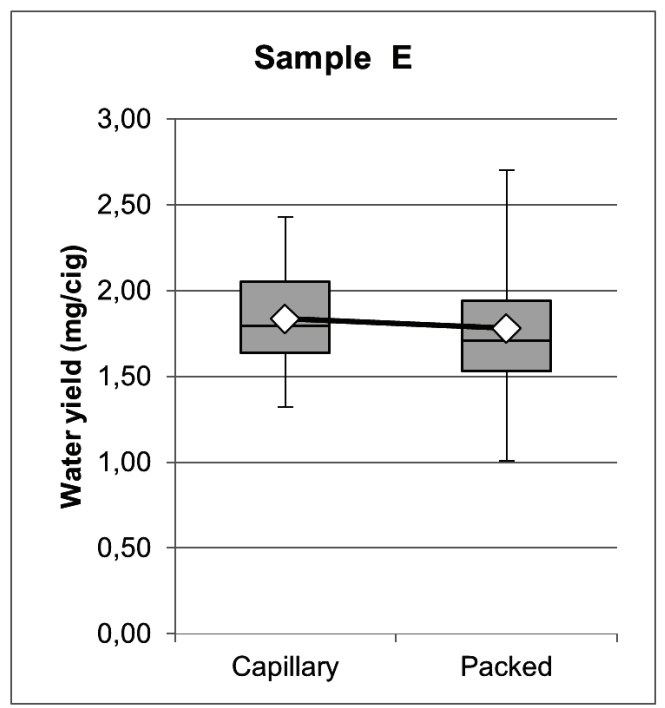

Figure 5. Box plots of water yield for sample E.

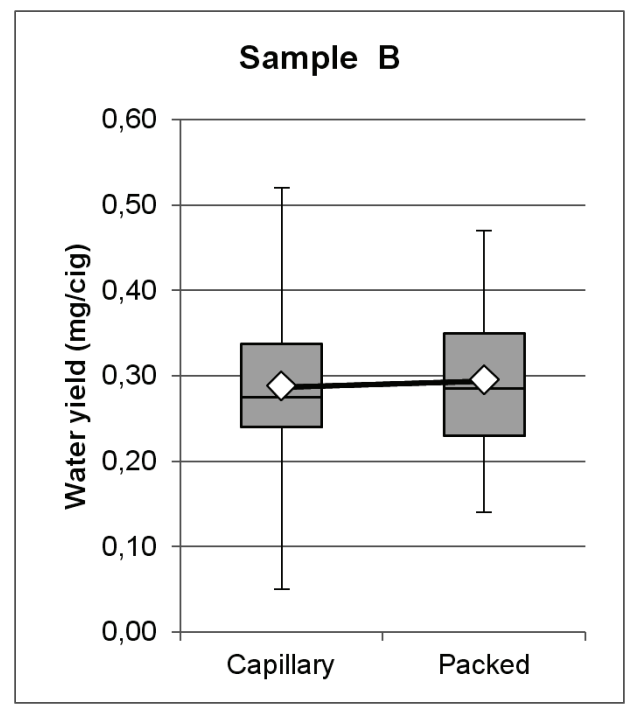

Figure 2. Box plots of water yield for sample B.

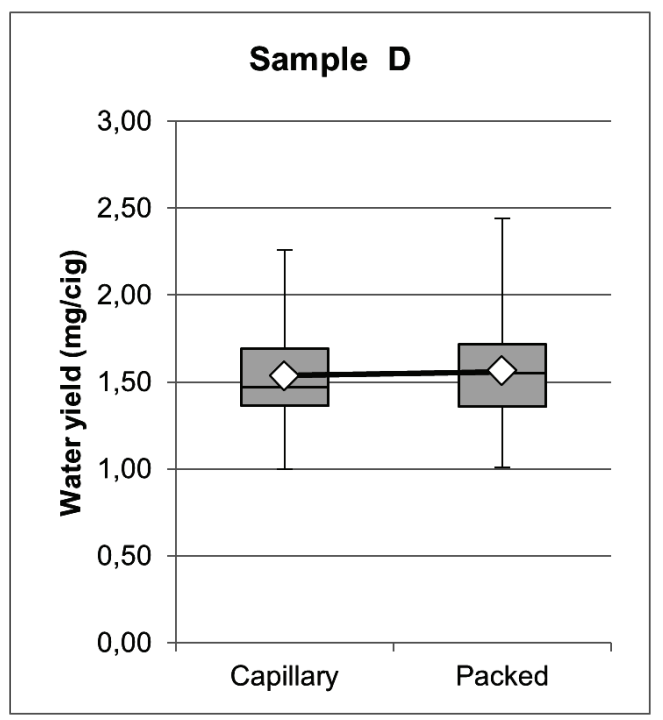

Figure 4. Box plots of water yield for sample $D$.

The diamond-shaped symbols indicate the mean values. The interquartile range (IQR) of capillary columns for sample A was narrower than the IQR of packed columns. IQR of capillary columns for samples B, C, D and E were almost identical to those of the packed columns. The $t$-test of Welch was applied to confirm the statistical difference in water yield determination by packed columns and capillary columns. The results of the $t$-test are listed in Table 7.

No significant difference between packed columns and capillary columns in water yield determination was observed in all test samples.

4. Comparison of water yields by smoking machine type and GC column type

Datasets were classified into four groups by the combination of GC column type and smoking machine type.

Box plots for each test sample are shown in Figures 6 to 10. 


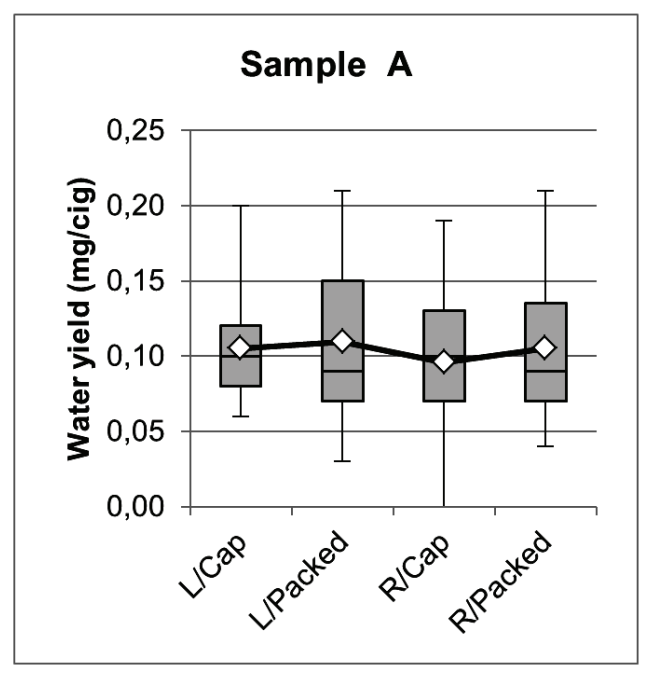

Figure 6. Box plots of water yield for sample A.

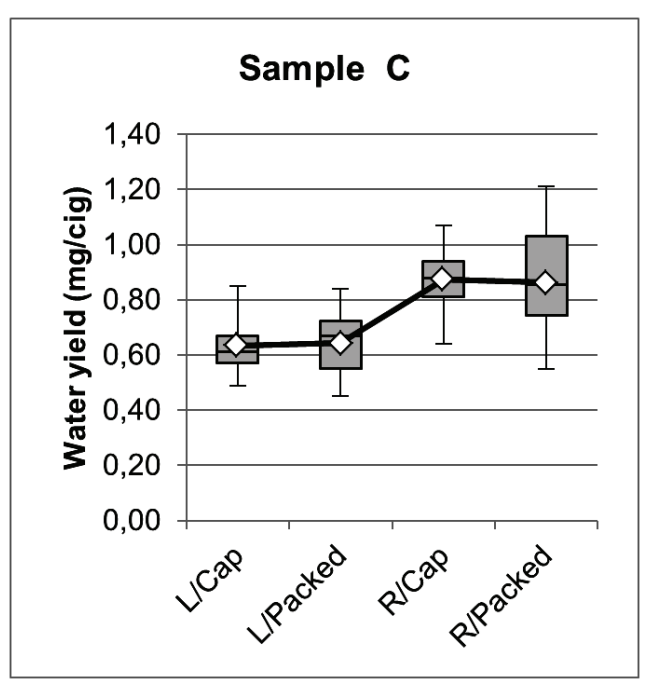

Figure 8. Box plots of water yield for sample C.

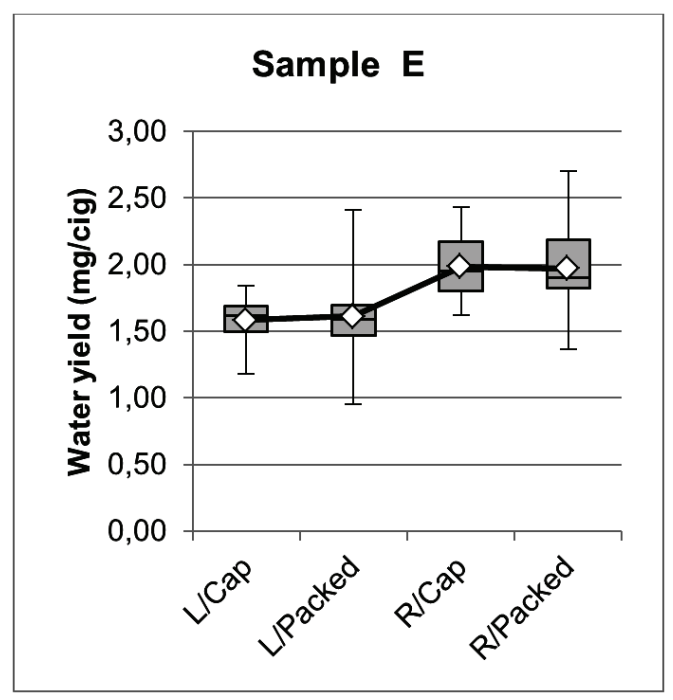

Figure 10. Box plots of water yield for sample E.

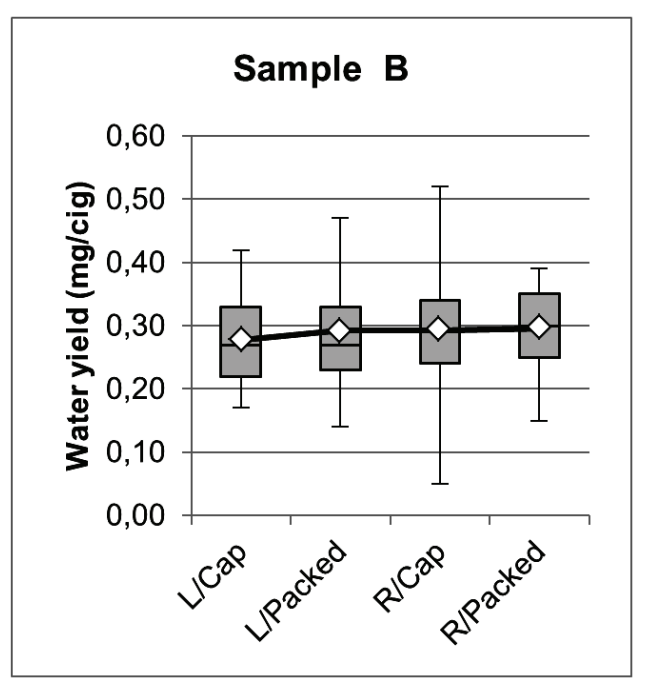

Figure 7. Box plots of water yield for sample B.

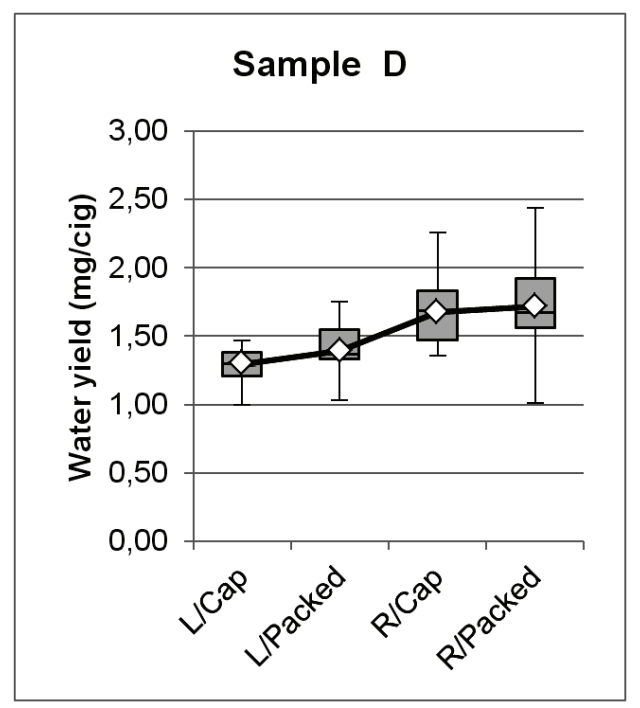

Figure 9. Box plots of water yield for sample D.

Table 7. Results of $t$-test in water yields between capillary columns and packed columns.

\begin{tabular}{|c|c|c|c|c|c|c|}
\hline \multirow{2}{*}{$\begin{array}{l}\text { Sample } \\
\text { code }\end{array}$} & \multirow{2}{*}{$\begin{array}{c}\text { "Tar" } \\
\text { (mg/cig) }\end{array}$} & \multicolumn{2}{|c|}{ Capillary (mg/cig) } & \multicolumn{2}{|c|}{ Packed (mg/cig) } & \multirow{2}{*}{$t$-test ${ }^{\mathrm{a}}$} \\
\hline & & Mean & SD & Mean & SD & \\
\hline A & 1 & 0.097 & 0.043 & 0.104 & 0.052 & ns \\
\hline B & 3 & 0.287 & 0.089 & 0.290 & 0.074 & ns \\
\hline C & 6 & 0.785 & 0.155 & 0.753 & 0.188 & ns \\
\hline $\mathrm{D}$ & 10 & 1.534 & 0.272 & 1.558 & 0.321 & ns \\
\hline$E$ & 14.1 & 1.836 & 0.287 & 1.791 & 0.376 & ns \\
\hline
\end{tabular}

${ }^{a} t$-test ns: not significant 
L/Cap means a combination of linear smoking machine and capillary column. L/Packed means a com bination of linear smoking machine and packed column. R/Cap means a combination of rotary smoking machine and capillary column. $\mathrm{R} /$ Packed means a combination of rotary smoking machine and capillary column.

IQR and median of the four groups for samples A and B were almost identical. But IQR and median of rotary and linear smoking machines seemed to be different for samples C, D and E. The results of the $t$-test are listed in Tables 8 and 9. A statistically significant difference in water yields was not observed between capillary columns and packed columns within the same type of smoking machine. On the other hand, statistically significant differences in water yields were observed for samples C, D and $\mathrm{E}$ between rotary smoking machines and linear smoking machines within the same type of GC column.

\section{Repeatability and reproducibility estimation}

The estimated values, which were calculated for all types of GC columns, capillary columns and packed columns are listed in Table 10. In comparison with repeatability and reproducibility defined in ISO 10362-1:1999, the estimated repeatability and reproducibility tends to be smaller than in ISO 10362-1:1999.

\section{DISCUSSION}

\section{Comparison of capillary column with packed column}

CRUMPLER et al. (4) also reported that there was no significant difference in water yield of CM8 between packed columns and capillary columns.
In our study, we could show that no significant difference was observed for water yields in cigarette smoke condensate between capillary and packed columns, not only from CM8 but also from other test samples, covering the majority of "tar" value products that are sold in the market.

Comparison of water yields by smoking machine type and GC column type

There was no significant difference in water yields between linear type smoking machines and rotary type smoking machines for samples A and B, which had the lowest water yields. On the other hand, the water yields for samples C, D and $\mathrm{E}$ by rotary type smoking machines were higher than those by linear type smoking machine.

The differences in water yields between rotary and linear smoking machines were already observed in the CORESTA Harmonization Study in 1991 (10) and in the CORESTA Collaborative Study conducted by CORESTA CO SubCommittee (11). Although the differences in $\mathrm{CO}$ yields and NFDPM were improved and the differences in water yields became smaller through the improvement of air flow around cigarettes, higher water yields were still observed in the results obtained with rotary smoking machines under the ISO smoking regime $(4,12)$. Nevertheless, such a difference is no real influence in case of evaluation of the data from each smoking machine type. Comparisons between the two types of columns were carried out with a wider range of "tar" yields for each smoking machine type. This evaluation did not show significant difference between the data from packed columns and capillary columns.

Furthermore it was confirmed that there was no significant difference in the lower range of water yields between packed columns and capillary columns, with or without distinction of smoking machine type.

Table 8. Results of $t$-test in water yields between capillary and packed column within same type of smoking machine (unit: $\mathrm{mg} / \mathrm{cig}$ ).

\begin{tabular}{|c|c|c|c|c|c|c|c|c|c|c|}
\hline \multirow{3}{*}{$\begin{array}{c}\text { Sample } \\
\text { code }\end{array}$} & \multicolumn{5}{|c|}{ Linear } & \multicolumn{5}{|c|}{ Rotary } \\
\hline & \multicolumn{2}{|c|}{ Capillary } & \multicolumn{2}{|c|}{ Packed } & \multirow{2}{*}{$t$-test ${ }^{a}$} & \multicolumn{2}{|c|}{ Capillary } & \multicolumn{2}{|c|}{ Packed } & \multirow{2}{*}{$t$-test $^{a}$} \\
\hline & Mean & SD & Mean & SD & & Mean & SD & Mean & SD & \\
\hline$A$ & 0.106 & 0.041 & 0.102 & 0.058 & ns & 0.092 & 0.044 & 0.101 & 0.047 & ns \\
\hline$B$ & 0.273 & 0.065 & 0.286 & 0.082 & ns & 0.29 & 0.101 & 0.296 & 0.068 & ns \\
\hline $\mathrm{C}$ & 0.632 & 0.100 & 0.645 & 0.113 & ns & 0.874 & 0.103 & 0.861 & 0.188 & ns \\
\hline $\mathrm{D}$ & 1.287 & 0.137 & 1.391 & 0.193 & ns & 1.676 & 0.229 & 1.718 & 0.338 & ns \\
\hline$E$ & 1.576 & 0.159 & 1.614 & 0.324 & ns & 1.988 & 0.23 & 1.969 & 0.346 & ns \\
\hline
\end{tabular}

${ }^{a} t$-test ns: not significant

Table 9. Results of $t$-test in water yields between linear and rotary smoking machine within same type of GC column (unit: $\mathrm{mg} / \mathrm{cig}$ ).

\begin{tabular}{|c|c|c|c|c|c|c|c|c|c|c|}
\hline \multirow{3}{*}{$\begin{array}{l}\text { Sample } \\
\text { code }\end{array}$} & \multicolumn{5}{|c|}{ Capillary } & \multicolumn{5}{|c|}{ Packed } \\
\hline & \multicolumn{2}{|c|}{ Linear } & \multicolumn{2}{|c|}{ Rotary } & \multirow{2}{*}{$t$-test ${ }^{a}$} & \multicolumn{2}{|c|}{ Linear } & \multicolumn{2}{|c|}{ Rotary } & \multirow{2}{*}{$t$-test ${ }^{2}$} \\
\hline & Mean & SD & Mean & SD & & Mean & SD & Mean & SD & \\
\hline$A$ & 0.106 & 0.041 & 0.092 & 0.044 & ns & 0.102 & 0.058 & 0.101 & 0.047 & ns \\
\hline B & 0.273 & 0.065 & 0.290 & 0.101 & ns & 0.286 & 0.082 & 0.296 & 0.068 & ns \\
\hline $\mathrm{C}$ & 0.632 & 0.100 & 0.874 & 0.103 & $* *$ & 0.645 & 0.113 & 0.861 & 0.188 & $* *$ \\
\hline $\mathrm{D}$ & 1.287 & 0.137 & 1.676 & 0.229 & $* *$ & 1.391 & 0.193 & 1.718 & 0.338 & $* *$ \\
\hline$E$ & 1.576 & 0.159 & 1.988 & 0.230 & ** & 1.614 & 0.324 & 1.969 & 0.346 & ** \\
\hline
\end{tabular}

a $t$-test ns: not significant, ${ }^{* *} 1 \%$ significant 
Table 10. Estimated $\boldsymbol{r}$ and $\boldsymbol{R}$ for all water data, capillary columns and packed columns (unit: $\mathrm{mg} / \mathrm{cig}$ ).

\begin{tabular}{c|c|c|c|c|c|c|c|c|c}
\hline \multirow{2}{*}{$\begin{array}{c}\text { Sample } \\
\text { code }\end{array}$} & \multicolumn{3}{|c|}{ All data } & \multicolumn{3}{c}{ Capillary columns } & \multicolumn{2}{c}{ Packed columns } \\
\cline { 2 - 8 } & Mean & $r$ & $R$ & Mean & $r$ & $R$ & \multicolumn{2}{c}{ Mean } & 0.13 \\
A & 0.101 & 0.129 & 0.176 & 0.097 & 0.131 & 0.169 & 0.104 & 0.187 \\
B & 0.286 & 0.225 & 0.307 & 0.284 & 0.209 & 0.312 & 0.29 & 0.243 \\
C & 0.771 & 0.267 & 0.534 & 0.785 & 0.281 & 0.505 & 0.753 & 0.246 \\
D & 1.525 & 0.365 & 0.818 & 1.518 & 0.349 & 0.773 & 1.534 & 0.379 \\
E & 1.816 & 0.424 & 0.999 & 1.836 & 0.432 & 0.895 & 1.791 & 0.414 \\
\hline
\end{tabular}

Table 11. Repeatability and reproducibility in ISO 10362-1:1999.

\begin{tabular}{c|c|c}
\hline $\begin{array}{c}\text { Mean value } m_{\mathrm{w}} \\
(\mathrm{mg} / \mathrm{cig})\end{array}$ & $\begin{array}{c}\text { Repeatability limit } r \\
(\mathrm{mg} / \mathrm{cig})\end{array}$ & $\begin{array}{c}\text { Reproducibility limit } R \\
(\mathrm{mg} / \mathrm{cig})\end{array}$ \\
\hline 0.083 & 0.154 & 0.241 \\
0.153 & 0.228 & 0.353 \\
0.338 & 0.272 & 0.381 \\
0.962 & 0.407 & 0.734 \\
1.595 & 0.561 & 0.935 \\
3.187 & 0.908 & 1.680 \\
\hline
\end{tabular}

Comparison of estimated repeatability and reproducibility with the past results

The comparison of repeatability and reproducibility estimated by using all datasets as well as datasets classified by GC column type were made via an $F$-ratio test with a Bonferroni adjustment for multiple comparisons. No significant differences between capillary and packed columns were observed when comparing repeatability and reproducibility among the samples.

Estimated $r$ and $R$ listed in Table 10 were compared to those of ISO 10362-1:1999 (1) listed in Table 11 by use of 95\% of upper limit of prediction bands (ULP) and lower limit of prediction bands (LLP). The ULP and LLP were determined by a linear regression analysis of mean, repeatability and reproducibility defined in ISO 10362-1:1999 (1).

The repeatability estimated by using all datasets as well as datasets classified by GC column type were plotted with those of ISO 10362-1:1999 and 95\% of upper and lower limits for prediction bands (Figure 11).

The estimated repeatability for samples A and B were within the upper and lower limits for prediction bands. All of the estimated repeatability for samples C, D and E were smaller than $95 \%$ of lower limit for prediction band. This means that the estimated repeatability might be similar or smaller than the values in ISO 10362-1:1999.

The reproducibility estimated by using all datasets as well as datasets classified by GC column types were plotted with those of ISO 10362-1:1999 and 95\% of upper and lower limits for prediction bands (Figure 12).

The estimated reproducibility of packed columns was almost within the $95 \%$ upper and lower limit of prediction bands. On the other hand, the estimated reproducibility of capillary columns was smaller than $95 \%$ of lower limit of prediction band. This means that the estimated reproducibility of capillary columns is better than the reproducibility in ISO10362-1: 1999.
The estimated $r$ and $R$ by capillary column, packed column and all types of GC column are within $95 \%$ of upper limit for prediction band.

The estimated $r$ and $R$ for all data, capillary column and packed column are confirmed to be comparable to those of ISO 10362-1:1999, and these values can cover a wider range of water yields by ISO Smoking Regime.

The comparative results of water yields and estimated $r$ and $R$ strongly suggests that capillary columns are an appropriate alternative column for the gas chromatographic procedure of ISO 10362-1.

\section{ACKNOWLEDGEMENT}

The corresponding author wishes to thank Mr. Hiromoto Yamazaki, the convener of ISO/TC126 Working Group 17, all the members of this working group, and the contribution from the participants of $24^{\text {th }}$ Asia Collaborative Study.

\section{REFERENCES}

1. International Organization for Standardization (ISO): International Standard ISO 10362-1:1999. Cigarettes Determination of Water in Total Particulate Matter from the Mainstream Smoke - Part 1: Gas-Chromatographic Method; ISO, Geneva, Switzerland, 1999.

2. International Organization for Standardization (ISO): International Standard ISO 10315:2013 (ED 3). Cigarettes - Determination of Nicotine in Smoke Condensates - Gas-Chromatographic Method; ISO, Geneva, Switzerland, 2013.

3. Cooperation Centre for Scientific Research Relative to Tobacco (CORESTA): CORESTA Recommended Method No. 57: Determination of Water in Tobacco and Tobacco Products by Gas Chromatographic Analysis; August 2018. Available at: https://www. coresta.org/determination-water-tobacco-and-tobaccoproducts-gas-chromatographic-analysis-29180.html (accessed August 2020)

4. Crumpler, L.A., G. Jaccard, and D.T. Djoko: CORESTA Routine Analytical Chemistry Sub-Group, Technical Report: Use of Capillary GC Columns for the Determination of Water in Cigarette Mainstream Smoke; March 2018. Available at: https://www. coresta.org/use-capillary-gc-columns-determinationwater-cigarette-mainstream-smoke-3 1406.html (accessed August 2020) 


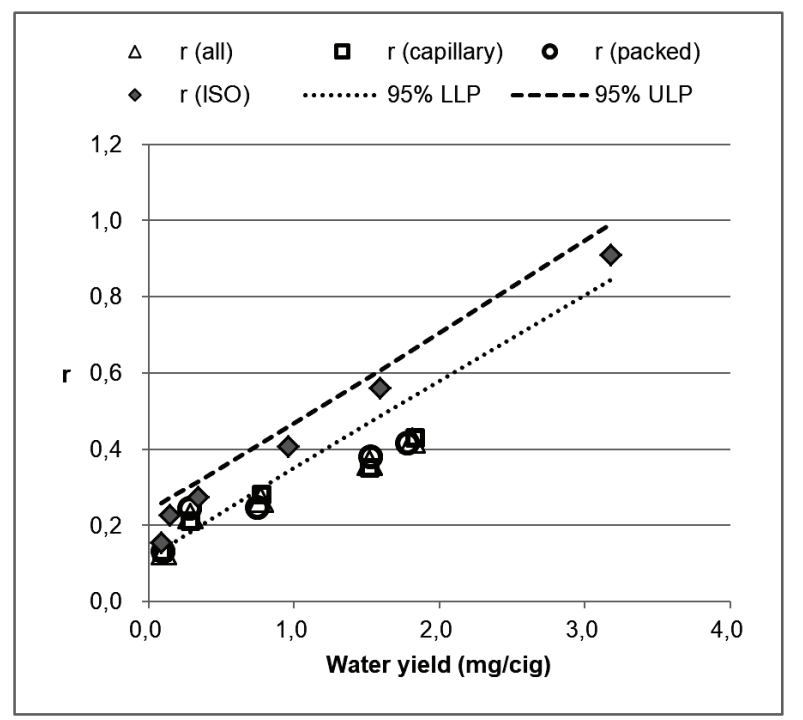

Figure 11. Comparison of estimated repeatability $(r)$ for all, capillary and packed columns with those of ISO 10362-1 and upper and lower limits for prediction bands.

95\% LLP: $95 \%$ of lower limit for prediction bands 95\% ULP: $95 \%$ of upper limit for prediction bands

5. Takahashi, H. and M. Tanaka: Statistical Analysis for the Results Obtained by Capillary Columns and Packed Columns on the Determination of Water in Smoke Condensate at the $24^{\text {th }}$ Asia Collaborative Study; Presented at the $26^{\text {th }}$ Asia Collaborative Study Meeting, Seoul, South Korea, May 2019.

6. Cooperation Centre for Scientific Research Relative to Tobacco (CORESTA): CORESTA Approved Monitor No.8 (CM8) Use and Conditions; June 13, 2015. Available at: https://www.coresta.org/sites/default/ files/pages/CM8_UseConditions-June2015_0.pdf (accessed August 2020)

7. International Organization for Standardization (ISO): International Standard ISO 5725-2:1994. Accuracy (Trueness and Precision) of Measurement Methods and Results - Part 2: Basic Method for the Determination of Repeatability and Reproducibility of a Standard Measurement Method; ISO, Geneva, Switzerland, 1994.

8. Grubbs, F.E. and G. Beck: Extension of Sample Sizes and Percentage Points for Significance Tests of Outlying Observations; Technometrics 14 (1972) 847-854. DOI: $10.2307 / 1267134$

9. 't Lam, R.U.E.: Scrutiny of Variance Results for Outliers: Cochran's Test Optimized; Anal. Chim. Acta 659 (2010) 68-84. DOI: 10.1016/j.aca.2009.11.032

10. Task Force on the Review of Smoking Methods: CORESTA Report 1991-1. The Determination of Repeatability [r] and Reproducibility [R] for the Measurement of Nicotine-Free Dry Particulate Matter (NFDPM), Nicotine, Water Using CORESTA Recommended Methods 7, 8, 21, 22, 23 and 25;

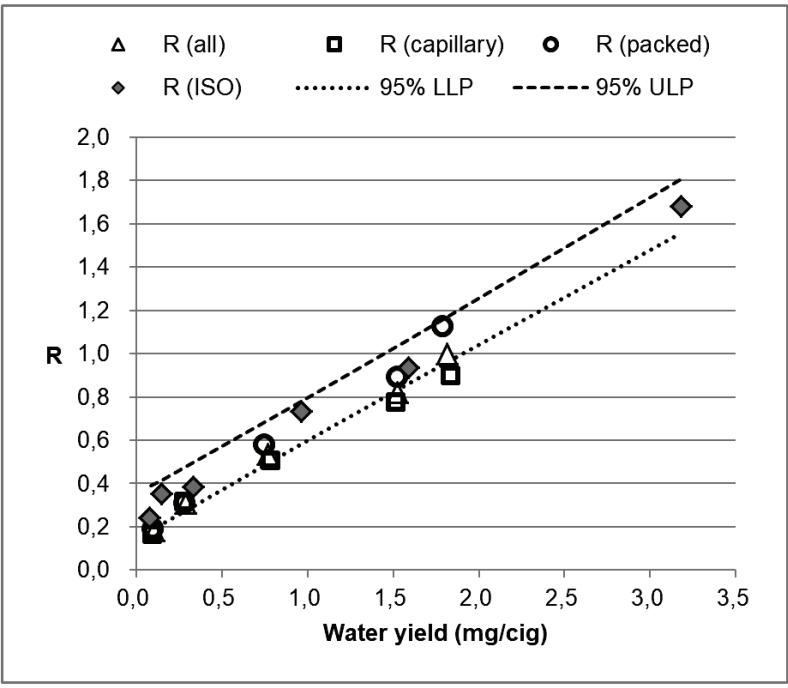

Figure 12. Comparison of estimated reproducibility (R) for all capillary and packed columns with those of ISO 10362-1 and upper and lower limits for prediction bands.

95\% LLP: $95 \%$ of lower limit for prediction bands 95\% ULP: $95 \%$ of upper limit for prediction bands

CORESTA, 1991. Available at: https://www.coresta. org/review-smoking-methods-determination-rrmeasurement-nfdpm-nicotine-and-water-29288.html (accessed August 2020)

11. Cooperation Centre for Scientific Research Relative to Tobacco (CORESTA), Routine Analytical Chemistry Sub-Group CO Sub-Committee: CORESTA Collaborative Study for the Estimation of the Repeatability and Reproducibility of the Measurement of NicotineFree Particulate Matter, Nicotine and CO in Smoke Using the ISO Smoking Methods; October 2003. Available at: https://www.coresta.org/coresta-collaborative-study-estimation-repeatability-and-reproducibility-measurement-nicotine-free (accessed August 2020)

12. International Organization for Standardization (ISO): International Standard ISO/TR 19478-1:2014: ISO and Health Canada Intense Smoking Parameters - Part 1: Results of an International Machine Smoking; ISO, Geneva, Switzerland, 2014.

Corresponding author:

Hisayuki Takahashi

Quality Assurance Division Sumida Bldg. Branch Office Japan Tobacco Inc.

1-17-7 Yokokawa, Sumida-ku,

Tokyo, Japan

E-mail: hisayuki.a.takahashi@jt.com 
APPENDIX A. Table A. List of Participating Laboratories

\begin{tabular}{|c|c|c|}
\hline No. & Name of participating laboratories & Country \\
\hline 1 & Papierfabrik Wattens GmbH \& Co KG & Austria \\
\hline 2 & British American Tobacco Bangladesh & Bangladesh \\
\hline 3 & Philip Morris Brazil Industria \& Comercio Ltda & Brazil \\
\hline $4^{*}$ & $\mathrm{RBH}$ Inc. & Canada \\
\hline 5 & Beijing Tobacco Monopoly Bureau & China \\
\hline 6 & China National Tobacco Corporation Shandong Branch & China \\
\hline 7 & China National Tobacco Corporation Sichuan Branch & China \\
\hline $8^{*}$ & China National Tobacco Quality Supervision \& Test Centre & China \\
\hline 9 & China Tobacco Co. Shannxi Provincial Co. & China \\
\hline 10 & Guangdong Tobacco Quality Supervision and Test Station & China \\
\hline 11 & Guizhou Province Tobacco Quality Supervision \& Test Station & China \\
\hline 12 & Henan Tobacco Quality Supervision \& Test Station & China \\
\hline 13 & Hubei Tobacco Quality Supervision and Test Station & China \\
\hline 14 & Inner Mongolia Tob. Monopoly Quality Supervision and Test Center & China \\
\hline 15 & Ji Lin Tobacco Quality Supervision \& Inspection Station & China \\
\hline 16 & Shanghai Tobacco Group Co., Ltd & China \\
\hline 17 & Yunnan Comtestor co., LTD & China \\
\hline 18 & Yunnan Tobacco Quality Supervision \& Test Station & China \\
\hline 19 & Borgwaldt $\mathrm{KC} \mathrm{GmbH}$ & Germany \\
\hline $20^{*}$ & JT International Germany GmbH & Germany \\
\hline 21 & Reemtsma Cigarettenfabriken $\mathrm{GmbH}$ & Germany \\
\hline 22 & Hong Kong Government Laboratory & Hong Kong \\
\hline $23^{*}$ & Godfrey Phillips India Ltd. & India \\
\hline $24^{*}$ & ITC Ltd. & India \\
\hline 25 & VST Industries Ltd. & India \\
\hline $26^{*}$ & PT. Bentoel Prima & Indonesia \\
\hline $27^{*}$ & PT. Djarum & Indonesia \\
\hline $28^{*}$ & PT. Gudang Garam Tbk. & Indonesia \\
\hline 29 & PT. Gelora Djaja & Indonesia \\
\hline $30^{*}$ & PT. HM Sampoerna. Tbk & Indonesia \\
\hline 31 & PT. Nojorono Tob. Intl. & Indonesia \\
\hline 32 & PT. Sentosa Abadi Purwosari & Indonesia \\
\hline $33^{*}$ & PT Sumatra Tobacco Trading Company & Indonesia \\
\hline 34 & UPT PSMB-Lembaga Tembakau Jember & Indonesia \\
\hline $35^{*}$ & Japan Tobacco Inc. & Japan \\
\hline 36 & TIOJ Testing Laboratory & Japan \\
\hline 37 & Royal Scientific Society & Jordan \\
\hline 38 & BAT Korea & Korea \\
\hline 39 & Korea Conformity Laboratories (KCL) & Korea \\
\hline 40 & KT\&G & Korea \\
\hline 41 & Ministry of Food and Drug Safety & Korea \\
\hline $42^{*}$ & Philip Morris Korea & Korea \\
\hline 43 & Tobacco Smoke Analysis Center & Korea \\
\hline 44 & Public Health Laboratory & Macao \\
\hline 45 & BAT AsPac Service Centre & Malaysia \\
\hline 46 & National Public Health Laboratory & Malaysia \\
\hline $47^{*}$ & Philip Morris Mexico Productos Y Servicios & Mexico \\
\hline 48 & Surya Nepal Pvt. Ltd. & Nepal \\
\hline 49 & Pakistan Tobacco Company & Pakistan \\
\hline $50^{*}$ & Mighty Corporation & Philippines \\
\hline 51 & PMFTC Inc. & Philippines \\
\hline 52 & British American Tobacco Singapore & Singapore \\
\hline 53 & Philip Morris International & Switzerland \\
\hline 54 & Food \& Drug Administration, Ministry of Health \& Welfare & Taiwan \\
\hline $55^{*}$ & Taiwan Cigarette and Liquor Cop. & Taiwan \\
\hline 56 & Taiwan Tobacco and Liquor Corporation -1 & Taiwan \\
\hline 57 & Taiwan Tobacco and Liquor Corporation -2 & Taiwan \\
\hline 58 & Thailand Tobacco Monopoly & Thailand \\
\hline $59^{*}$ & Essentra Scientific Services & U.K. \\
\hline 60 & Altria Client Services & U.S.A. \\
\hline 61 & Enthalpy Analytical, Inc. & U.S.A. \\
\hline 62 & R.J. Reynolds Tobacco Co. & U.S.A. \\
\hline 63 & National Laboratory \& Research Center & UAE \\
\hline 64 & Compañia Industrial de Tabacos Montepaz S.A. & Uruquay \\
\hline
\end{tabular}

Note: Laboratories marked with * provided more than one data set obtained by using various combinations of linear and rotary smoking machines. 


\section{APPENDIX B. Raw Data}

A unique alpha-numeric code was assigned to each data set received from a laboratory reflecting the type of smoking machine used and the specific data set submitted.

The numerals (01-64) in the code denote the laboratory, alphabet characters A, B, C, D and E represent the specific data set and the alphabet characters $\mathrm{L}$ or $\mathrm{R}$ refer to the linear or rotary smoking machine used by that laboratory.

Table B1. Raw data of water yields for sample A (unit: $\mathrm{mg} / \mathrm{cig}$ )

Table B2. Raw data of water yields for sample B (unit: $\mathrm{mg} / \mathrm{cig}$ )

Table B3. Raw data of water yields for sample C (unit: $\mathrm{mg} / \mathrm{cig}$ )

Table B4. Raw data of water yields for sample D (unit: $\mathrm{mg} / \mathrm{cig}$ )

Table B5. Raw data of water yields for sample E (unit: $\mathrm{mg} / \mathrm{cig}$ ) 
Table B1. Raw data of water yields for sample A (unit: $\mathrm{mg} / \mathrm{cig}$ ).

\begin{tabular}{|c|c|c|c|c|c|c|c|c|c|c|c|}
\hline \multirow{2}{*}{ No. } & \multirow{2}{*}{$\begin{array}{l}\text { Smoking } \\
\text { machine }\end{array}$} & \multirow{2}{*}{$\begin{array}{l}\text { GC column } \\
\text { type }\end{array}$} & \multirow{2}{*}{$\begin{array}{l}\text { Lab. } \\
\text { Code }\end{array}$} & \multicolumn{6}{|c|}{ No. of run } & \multirow{2}{*}{ Mean } & \multirow{2}{*}{ SD } \\
\hline & & & & 1 & 2 & 3 & 4 & 5 & 6 & & \\
\hline 1 & $\mathrm{R}$ & Capillary & $01 R$ & 0.02 & 0.04 & 0.08 & 0.10 & 0.06 & 0.09 & 0.07 & 0.031 \\
\hline 2 & $\mathrm{R}$ & Capillary & $02 \mathrm{R}$ & 0.15 & 0.17 & 0.02 & 0.04 & 0.12 & 0.06 & 0.09 & 0.061 \\
\hline 3 & $\mathrm{~L}$ & Packed & $03 A L$ & 0.04 & 0.15 & 0.17 & 0.03 & 0.02 & 0.05 & 0.08 & 0.066 \\
\hline 4 & $\mathrm{R}$ & Packed & 03BR & 0.13 & 0.05 & 0.13 & 0.01 & 0.03 & 0.05 & 0.07 & 0.052 \\
\hline 5 & $\mathrm{~L}$ & Packed & 04L & 0.17 & 0.11 & 0.17 & 0.17 & 0.14 & 0.16 & 0.15 & 0.024 \\
\hline 6 & L & Packed & $05 \mathrm{~L}$ & 0.07 & 0.08 & 0.09 & 0.11 & 0.11 & 0.15 & 0.10 & 0.029 \\
\hline 7 & $\mathrm{~L}$ & Capillary & 06AL & 0.12 & 0.08 & 0.10 & 0.04 & 0.12 & 0.08 & 0.09 & 0.030 \\
\hline 8 & $\mathrm{~L}$ & Capillary & 06BL & 0.33 & 0.22 & 0.06 & 0.29 & 0.12 & 0.15 & 0.20 & 0.104 \\
\hline 9 & $\mathrm{R}$ & Capillary & 07AR & 0.19 & 0.08 & 0.11 & 0.11 & 0.13 & 0.11 & 0.12 & 0.035 \\
\hline 10 & $\mathrm{R}$ & Capillary & 07BR & 0.14 & 0.13 & 0.05 & 0.10 & 0.08 & 0.07 & 0.10 & 0.036 \\
\hline 11 & $\mathrm{~L}$ & Capillary & 07CL & 0.06 & 0.08 & 0.08 & 0.03 & 0.09 & 0.08 & 0.07 & 0.022 \\
\hline 12 & $\mathrm{R}$ & Capillary & 08R & 0.16 & 0.08 & 0.06 & 0.12 & 0.06 & 0.06 & 0.09 & 0.041 \\
\hline 13 & $\mathrm{R}$ & Capillary & 09R & 0.19 & 0.01 & 0.10 & 0.01 & 0.16 & 0.02 & 0.08 & 0.080 \\
\hline 14 & $\mathrm{R}$ & Capillary & $10 \mathrm{R}$ & 0.00 & 0.03 & 0.06 & 0.06 & 0.06 & 0.02 & 0.04 & 0.023 \\
\hline 15 & $\mathrm{~L}$ & Capillary & $11 \mathrm{~L}$ & 0.10 & 0.02 & 0.11 & 0.08 & 0.02 & 0.02 & 0.06 & 0.043 \\
\hline 16 & $\mathrm{R}$ & Packed & $12 \mathrm{R}$ & 0.07 & 0.05 & 0.08 & 0.09 & 0.10 & 0.12 & 0.08 & 0.023 \\
\hline 17 & $\mathrm{R}$ & Capillary & $13 A R$ & 0.10 & 0.12 & 0.10 & 0.13 & 0.12 & 0.20 & 0.13 & 0.037 \\
\hline 18 & $\mathrm{R}$ & Capillary & 13BR & 0.14 & 0.14 & 0.11 & 0.11 & 0.12 & 0.15 & 0.13 & 0.017 \\
\hline 19 & $\mathrm{R}$ & Packed & $14 R$ & 0.16 & 0.17 & 0.16 & 0.19 & 0.18 & 0.14 & 0.17 & 0.017 \\
\hline 20 & $\mathrm{R}$ & Capillary & $15 A R$ & 0.20 & 0.22 & 0.13 & 0.10 & 0.11 & 0.10 & 0.14 & 0.053 \\
\hline 21 & $\mathrm{~L}$ & Capillary & $15 B L$ & 0.11 & 0.09 & 0.09 & 0.02 & 0.19 & 0.26 & 0.13 & 0.085 \\
\hline 22 & $\mathrm{R}$ & Packed & $16 \mathrm{R}$ & 0.03 & 0.05 & 0.13 & 0.07 & 0.02 & 0.17 & 0.08 & 0.059 \\
\hline 23 & $\mathrm{R}$ & Packed & 17AR & 0.08 & 0.10 & 0.08 & 0.09 & 0.09 & 0.12 & 0.09 & 0.015 \\
\hline 24 & $\mathrm{~L}$ & Packed & 17BL & 0.13 & 0.12 & 0.09 & 0.09 & 0.07 & 0.11 & 0.10 & 0.022 \\
\hline 25 & $\mathrm{R}$ & Capillary & 18AR & 0.09 & 0.10 & 0.10 & 0.10 & 0.09 & 0.10 & 0.10 & 0.004 \\
\hline 26 & $\mathrm{~L}$ & Capillary & 18BL & 0.09 & 0.08 & 0.11 & 0.06 & 0.07 & 0.10 & 0.09 & 0.019 \\
\hline 27 & $\mathrm{~L}$ & Capillary & $19 A L$ & 0.03 & 0.07 & 0.06 & 0.05 & 0.06 & 0.08 & 0.06 & 0.017 \\
\hline 28 & $\mathrm{R}$ & Capillary & 19BR & 0.13 & 0.18 & 0.12 & 0.09 & 0.17 & 0.09 & 0.13 & 0.038 \\
\hline 29 & $\mathrm{~L}$ & Capillary & $19 \mathrm{CL}$ & 0.09 & 0.09 & 0.06 & 0.06 & 0.08 & 0.07 & 0.08 & 0.014 \\
\hline 30 & $\mathrm{R}$ & Capillary & 19DR & 0.07 & 0.10 & 0.17 & 0.11 & 0.01 & 0.01 & 0.08 & 0.061 \\
\hline 31 & $\mathrm{~L}$ & Packed & 19EL & 0.07 & 0.07 & 0.04 & 0.07 & 0.05 & 0.06 & 0.06 & 0.013 \\
\hline 32 & L & Packed & $20 \mathrm{~L}$ & 0.09 & 0.06 & 0.06 & 0.06 & 0.06 & 0.05 & 0.06 & 0.014 \\
\hline 33 & $\mathrm{~L}$ & Capillary & $21 \mathrm{~L}$ & 0.13 & 0.12 & 0.13 & 0.13 & 0.13 & 0.13 & 0.13 & 0.004 \\
\hline 34 & $\mathrm{R}$ & Capillary & $22 \mathrm{R}$ & 0.04 & 0.10 & 0.05 & 0.09 & 0.11 & 0.27 & 0.11 & 0.083 \\
\hline 35 & $\mathrm{R}$ & Capillary & $23 R$ & 0.01 & 0.01 & 0.00 & 0.00 & 0.01 & 0.00 & 0.00 & 0.005 \\
\hline 36 & $\mathrm{R}$ & Capillary & $24 A R$ & 0.10 & 0.11 & 0.11 & 0.10 & 0.11 & 0.10 & 0.11 & 0.005 \\
\hline 37 & $\mathrm{~L}$ & Capillary & $24 \mathrm{BL}$ & 0.12 & 0.12 & 0.11 & 0.13 & 0.12 & 0.11 & 0.12 & 0.008 \\
\hline 38 & $\mathrm{R}$ & Packed & $25 \mathrm{R}$ & 0.09 & 0.08 & 0.11 & 0.10 & 0.10 & 0.12 & 0.10 & 0.014 \\
\hline 39 & $\mathrm{R}$ & Capillary & 26AR & 0.18 & 0.15 & 0.09 & 0.09 & 0.09 & 0.21 & 0.14 & 0.051 \\
\hline 40 & $\mathrm{R}$ & Capillary & 26BR & 0.18 & 0.14 & 0.09 & 0.06 & 0.20 & 0.15 & 0.14 & 0.052 \\
\hline 41 & $\mathrm{~L}$ & Capillary & $27 \mathrm{~L}$ & 0.28 & 0.12 & 0.03 & 0.00 & 0.01 & 0.08 & 0.09 & 0.105 \\
\hline 42 & $\mathrm{~L}$ & Packed & $28 \mathrm{~L}$ & 0.09 & 0.19 & 0.17 & 0.31 & 0.25 & 0.26 & 0.21 & 0.078 \\
\hline 43 & $\mathrm{~L}$ & Packed & $29 \mathrm{~L}$ & n.s. ${ }^{a}$ & n.s. & n.s. & n.s. & n.s. & n.s. & n.s. & n.s. \\
\hline 44 & $\mathrm{R}$ & Packed & $30 \mathrm{R}$ & 0.12 & 0.08 & 0.10 & 0.11 & 0.08 & 0.06 & 0.09 & 0.022 \\
\hline 45 & $\mathrm{~L}$ & Packed & 31L & 0.03 & 0.11 & 0.08 & 0.13 & 0.00 & 0.12 & 0.08 & 0.053 \\
\hline 46 & $\mathrm{R}$ & Capillary & $32 \mathrm{AR}$ & 0.08 & 0.02 & 0.09 & 0.09 & 0.03 & 0.07 & 0.06 & 0.031 \\
\hline 47 & $\mathrm{R}$ & Capillary & 32BR & 0.01 & 0.05 & 0.08 & 0.13 & 0.06 & 0.10 & 0.07 & 0.041 \\
\hline 48 & $\mathrm{R}$ & Capillary & $33 R$ & 0.05 & 0.07 & 0.05 & 0.03 & 0.05 & 0.06 & 0.05 & 0.011 \\
\hline 49 & $\mathrm{R}$ & Packed & $34 \mathrm{R}$ & 0.27 & 0.10 & 0.12 & 0.23 & 0.17 & 0.09 & 0.16 & 0.072 \\
\hline 50 & $\mathrm{~L}$ & Packed & $35 \mathrm{~L}$ & 0.06 & 0.10 & 0.15 & 0.27 & 0.00 & 0.09 & 0.11 & 0.092 \\
\hline 51 & $\mathrm{R}$ & Capillary & 36AR & 0.20 & 0.18 & 0.16 & 0.17 & 0.17 & 0.16 & 0.17 & 0.015 \\
\hline 52 & $\mathrm{R}$ & Capillary & 36BR & 0.18 & 0.17 & 0.24 & 0.17 & 0.16 & 0.23 & 0.19 & 0.034 \\
\hline 53 & $\mathrm{R}$ & Capillary & $37 A R$ & 0.00 & 0.04 & 0.21 & 0.05 & 0.01 & 0.14 & 0.08 & 0.084 \\
\hline 54 & $\mathrm{~L}$ & Capillary & $37 \mathrm{BL}$ & 0.01 & 0.16 & 0.13 & 0.13 & 0.22 & 0.00 & 0.11 & 0.087 \\
\hline 55 & $\mathrm{R}$ & Packed & $38 \mathrm{R}$ & 0.07 & 0.07 & 0.09 & 0.25 & 0.17 & 0.17 & 0.14 & 0.071 \\
\hline 56 & $\mathrm{R}$ & Packed & $39 R$ & 0.22 & 0.06 & 0.13 & 0.12 & 0.14 & 0.12 & 0.13 & 0.048 \\
\hline
\end{tabular}


Table B1. Continued.

\begin{tabular}{|c|c|c|c|c|c|c|c|c|c|c|c|}
\hline \multirow{2}{*}{ No. } & \multirow{2}{*}{$\begin{array}{l}\text { Smoking } \\
\text { machine }\end{array}$} & \multirow{2}{*}{$\begin{array}{c}\text { GC column } \\
\text { type }\end{array}$} & \multirow{2}{*}{$\begin{array}{l}\text { Lab. } \\
\text { Code }\end{array}$} & \multicolumn{6}{|c|}{ No. of run } & \multirow{2}{*}{ Mean } & \multirow{2}{*}{ SD } \\
\hline & & & & 1 & 2 & 3 & 4 & 5 & 6 & & \\
\hline 57 & $\mathrm{R}$ & Packed & 40R & 0.04 & 0.04 & 0.20 & 0.20 & 0.23 & 0.13 & 0.14 & 0.084 \\
\hline 58 & $\mathrm{R}$ & Capillary & 41R & 0.16 & 0.12 & 0.10 & 0.13 & 0.07 & 0.09 & 0.11 & 0.031 \\
\hline 59 & $\mathrm{~L}$ & Capillary & $42 \mathrm{~L}$ & 0.12 & 0.09 & 0.08 & 0.10 & 0.09 & 0.12 & 0.10 & 0.017 \\
\hline 60 & $\mathrm{~L}$ & Packed & 43AL & 0.20 & 0.17 & 0.18 & 0.18 & 0.18 & 0.32 & 0.21 & 0.057 \\
\hline 61 & $\mathrm{~L}$ & Packed & 43BL & 0.19 & 0.18 & 0.18 & 0.21 & 0.20 & 0.21 & 0.20 & 0.014 \\
\hline 62 & $\mathrm{~L}$ & Capillary & $44 \mathrm{AL}$ & 0.13 & 0.20 & 0.14 & 0.14 & 0.14 & -0.10 & 0.11 & 0.105 \\
\hline 63 & $\mathrm{~L}$ & Capillary & $44 \mathrm{BL}$ & -0.04 & -0.03 & 0.05 & 0.03 & 0.19 & 0.21 & 0.07 & 0.108 \\
\hline 64 & $\mathrm{R}$ & Packed & $45 R$ & 0.08 & 0.04 & 0.05 & 0.09 & 0.06 & 0.02 & 0.06 & 0.026 \\
\hline 65 & $\mathrm{~L}$ & Packed & $46 \mathrm{~L}$ & 0.00 & 0.13 & 0.00 & 0.00 & 0.00 & 0.06 & 0.03 & 0.054 \\
\hline 66 & $\mathrm{~L}$ & Packed & $47 \mathrm{~L}$ & 0.30 & 0.18 & 0.10 & 0.23 & 0.20 & 0.13 & 0.19 & 0.072 \\
\hline 67 & $\mathrm{~L}$ & Capillary & $48 \mathrm{~L}$ & 0.09 & 0.10 & 0.10 & 0.10 & 0.10 & 0.10 & 0.10 & 0.004 \\
\hline 68 & $\mathrm{R}$ & Packed & 49R & 0.24 & 0.28 & 0.09 & 0.28 & 0.19 & 0.19 & 0.21 & 0.071 \\
\hline 69 & $\mathrm{R}$ & Packed & 50AR & 0.01 & 0.07 & 0.10 & 0.15 & 0.07 & 0.01 & 0.07 & 0.054 \\
\hline 70 & $\mathrm{R}$ & Packed & 50BR & 0.03 & 0.05 & 0.05 & 0.00 & 0.08 & 0.00 & 0.04 & 0.031 \\
\hline 71 & $\mathrm{~L}$ & Packed & $50 \mathrm{CL}$ & 0.06 & 0.04 & 0.10 & 0.13 & 0.14 & 0.04 & 0.09 & 0.045 \\
\hline 72 & $\mathrm{R}$ & Capillary & 51R & 0.12 & 0.10 & 0.13 & 0.13 & 0.08 & 0.08 & 0.11 & 0.023 \\
\hline 73 & $\mathrm{R}$ & Capillary & $52 \mathrm{R}$ & 0.00 & 0.00 & 0.00 & 0.00 & 0.00 & 0.00 & 0.00 & 0.000 \\
\hline 74 & $\mathrm{~L}$ & Packed & $53 \mathrm{~L}$ & 0.08 & 0.06 & 0.05 & 0.05 & 0.07 & 0.04 & 0.06 & 0.015 \\
\hline 75 & $\mathrm{R}$ & Capillary & 54R & 0.11 & 0.10 & 0.07 & 0.10 & 0.06 & 0.11 & 0.09 & 0.021 \\
\hline 76 & $\mathrm{R}$ & unknown & 55R & 0.56 & 0.38 & 0.19 & 0.38 & 0.56 & 0.56 & 0.44 & 0.150 \\
\hline 77 & $\mathrm{~L}$ & Packed & $56 \mathrm{~L}$ & 0.88 & 1.58 & 1.50 & 1.99 & 1.34 & 1.27 & 1.43 & 0.368 \\
\hline 78 & $\mathrm{R}$ & Packed & 57R & 0.13 & 0.14 & 0.13 & 0.13 & 0.10 & 0.17 & 0.13 & 0.023 \\
\hline 79 & $\mathrm{~L}$ & Packed & $58 \mathrm{~L}$ & 0.04 & 0.05 & 0.08 & 0.11 & 0.08 & 0.04 & 0.07 & 0.028 \\
\hline 80 & $\mathrm{~L}$ & Packed & 59L & 0.23 & 0.57 & 1.82 & 0.35 & 1.00 & 0.33 & 0.72 & 0.607 \\
\hline 81 & $\mathrm{R}$ & Packed & 60AR & 0.08 & 0.09 & 0.06 & 0.07 & 0.05 & 0.06 & 0.07 & 0.015 \\
\hline 82 & $\mathrm{~L}$ & Packed & $60 \mathrm{BL}$ & 0.05 & 0.07 & 0.07 & 0.11 & 0.06 & 0.06 & 0.07 & 0.021 \\
\hline 83 & $\mathrm{R}$ & Packed & $61 \mathrm{R}$ & 0.13 & 0.13 & 0.14 & 0.13 & 0.12 & 0.14 & 0.13 & 0.008 \\
\hline 84 & $\mathrm{R}$ & Capillary & $62 \mathrm{R}$ & 0.01 & 0.12 & 0.02 & 0.00 & 0.05 & 0.04 & 0.04 & 0.043 \\
\hline 85 & $\mathrm{~L}$ & Capillary & $63 \mathrm{~L}$ & 0.19 & 0.17 & 0.18 & 0.19 & 0.18 & 0.19 & 0.18 & 0.008 \\
\hline 86 & $\mathrm{R}$ & Packed & $64 \mathrm{R}$ & 0.04 & 0.02 & 0.06 & 0.02 & 0.04 & 0.03 & 0.04 & 0.015 \\
\hline
\end{tabular}

a n.s. $=$ no submission 
Table B2. Raw data of water yields for sample B (unit: $\mathrm{mg} / \mathrm{cig}$ ).

\begin{tabular}{|c|c|c|c|c|c|c|c|c|c|c|c|}
\hline \multirow{2}{*}{ No. } & \multirow{2}{*}{$\begin{array}{l}\text { Smoking } \\
\text { machine }\end{array}$} & \multirow{2}{*}{$\begin{array}{l}\text { GC column } \\
\text { type }\end{array}$} & \multirow{2}{*}{$\begin{array}{l}\text { Lab. } \\
\text { code }\end{array}$} & \multicolumn{6}{|c|}{ No. of run } & \multirow{2}{*}{ Mean } & \multirow{2}{*}{ SD } \\
\hline & & & & 1 & 2 & 3 & 4 & 5 & 6 & & \\
\hline 1 & $\mathrm{R}$ & Capillary & 01R & 0.08 & 0.11 & 0.14 & 0.14 & 0.19 & 0.15 & 0.14 & 0.037 \\
\hline 2 & $\mathrm{R}$ & Capillary & $02 R$ & 0.30 & 0.37 & 0.20 & 0.22 & 0.30 & 0.42 & 0.30 & 0.084 \\
\hline 3 & $\mathrm{~L}$ & Packed & $03 A L$ & 0.15 & 0.24 & 0.23 & 0.18 & 0.12 & 0.12 & 0.17 & 0.053 \\
\hline 4 & $\mathrm{R}$ & Packed & 03BR & 0.16 & 0.18 & 0.13 & 0.18 & 0.11 & 0.13 & 0.15 & 0.031 \\
\hline 5 & $\mathrm{~L}$ & Packed & 04L & 0.33 & 0.25 & 0.35 & 0.33 & 0.31 & 0.39 & 0.33 & 0.046 \\
\hline 6 & $\mathrm{~L}$ & Packed & $05 \mathrm{~L}$ & 0.27 & 0.26 & 0.25 & 0.26 & 0.34 & 0.34 & 0.29 & 0.042 \\
\hline 7 & $\mathrm{~L}$ & Capillary & 06AL & 0.27 & 0.44 & 0.29 & 0.36 & 0.23 & 0.71 & 0.38 & 0.176 \\
\hline 8 & $\mathrm{~L}$ & Capillary & 06BL & 0.50 & 0.19 & 0.14 & 0.75 & 0.30 & 0.19 & 0.35 & 0.237 \\
\hline 9 & $\mathrm{R}$ & Capillary & 07AR & 0.49 & 0.47 & 0.39 & 0.36 & 0.48 & 0.39 & 0.43 & 0.056 \\
\hline 10 & $\mathrm{R}$ & Capillary & 07BR & 0.37 & 0.36 & 0.31 & 0.30 & 0.35 & 0.41 & 0.35 & 0.039 \\
\hline 11 & $\mathrm{~L}$ & Capillary & 07CL & 0.21 & 0.13 & 0.25 & 0.21 & 0.20 & 0.16 & 0.19 & 0.042 \\
\hline 12 & $\mathrm{R}$ & Capillary & 08R & 0.32 & 0.30 & 0.26 & 0.20 & 0.26 & 0.25 & 0.27 & 0.042 \\
\hline 13 & $\mathrm{R}$ & Capillary & 09R & 0.28 & 0.24 & 0.20 & 0.16 & 0.24 & 0.24 & 0.23 & 0.041 \\
\hline 14 & $\mathrm{R}$ & Capillary & $10 \mathrm{R}$ & 0.28 & 0.25 & 0.25 & 0.29 & 0.27 & 0.24 & 0.26 & 0.021 \\
\hline 15 & $\mathrm{~L}$ & Capillary & $11 \mathrm{~L}$ & 0.17 & 0.20 & 0.25 & 0.27 & 0.17 & 0.18 & 0.21 & 0.043 \\
\hline 16 & $\mathrm{R}$ & Packed & $12 R$ & 0.30 & 0.32 & 0.36 & 0.42 & 0.23 & 0.27 & 0.31 & 0.068 \\
\hline 17 & $\mathrm{R}$ & Capillary & $13 A R$ & 0.28 & 0.28 & 0.32 & 0.23 & 0.33 & 0.32 & 0.29 & 0.038 \\
\hline 18 & $\mathrm{R}$ & Capillary & 13BR & 0.50 & 0.32 & 0.29 & 0.30 & 0.32 & 0.31 & 0.34 & 0.079 \\
\hline 19 & $\mathrm{R}$ & Packed & $14 \mathrm{R}$ & 0.24 & 0.35 & 0.44 & 0.38 & 0.42 & 0.40 & 0.37 & 0.071 \\
\hline 20 & $\mathrm{R}$ & Capillary & 15AR & 0.35 & 0.35 & 0.28 & 0.34 & 0.33 & 0.25 & 0.32 & 0.042 \\
\hline 21 & $\mathrm{~L}$ & Capillary & $15 B L$ & 0.27 & 0.19 & 0.30 & 0.14 & 0.07 & 0.06 & 0.17 & 0.100 \\
\hline 22 & $\mathrm{R}$ & Packed & $16 \mathrm{R}$ & 0.13 & 0.34 & 0.30 & 0.25 & 0.19 & 0.42 & 0.27 & 0.105 \\
\hline 23 & $\mathrm{R}$ & Packed & 17AR & 0.24 & 0.26 & 0.23 & 0.30 & 0.30 & 0.29 & 0.27 & 0.031 \\
\hline 24 & $\mathrm{~L}$ & Packed & 17BL & 0.23 & 0.25 & 0.25 & 0.19 & 0.19 & 0.17 & 0.21 & 0.034 \\
\hline 25 & $\mathrm{R}$ & Capillary & 18AR & 0.29 & 0.38 & 0.36 & 0.37 & 0.35 & 0.34 & 0.35 & 0.034 \\
\hline 26 & $\mathrm{~L}$ & Capillary & 18BL & 0.21 & 0.28 & 0.31 & 0.32 & 0.38 & 0.31 & 0.30 & 0.056 \\
\hline 27 & $\mathrm{~L}$ & Capillary & $19 A L$ & 0.23 & 0.26 & 0.25 & 0.24 & 0.26 & 0.26 & 0.25 & 0.013 \\
\hline 28 & $\mathrm{R}$ & Capillary & 19BR & 0.29 & 0.27 & 0.25 & 0.34 & 0.26 & 0.23 & 0.28 & 0.039 \\
\hline 29 & $\mathrm{~L}$ & Capillary & $19 \mathrm{CL}$ & 0.28 & 0.28 & 0.26 & 0.24 & 0.28 & 0.25 & 0.27 & 0.018 \\
\hline 30 & $\mathrm{R}$ & Capillary & 19DR & 0.26 & 0.27 & 0.26 & 0.33 & 0.22 & 0.17 & 0.25 & 0.054 \\
\hline 31 & $\mathrm{~L}$ & Packed & 19EL & 0.23 & 0.23 & 0.22 & 0.21 & 0.21 & 0.23 & 0.22 & 0.010 \\
\hline 32 & L & Packed & $20 \mathrm{~L}$ & 0.31 & 0.30 & 0.22 & 0.24 & 0.31 & 0.26 & 0.27 & 0.039 \\
\hline 33 & $\mathrm{~L}$ & Capillary & $21 \mathrm{~L}$ & 0.27 & 0.25 & 0.26 & 0.26 & 0.27 & 0.24 & 0.26 & 0.012 \\
\hline 34 & $\mathrm{R}$ & Capillary & $22 \mathrm{R}$ & 0.21 & 0.25 & 0.29 & 0.30 & 0.38 & 0.34 & 0.29 & 0.061 \\
\hline 35 & $\mathrm{R}$ & Capillary & $23 R$ & 0.30 & 0.26 & 0.12 & 0.28 & 0.31 & 0.17 & 0.24 & 0.076 \\
\hline 36 & $\mathrm{R}$ & Capillary & $24 A R$ & 0.21 & 0.22 & 0.23 & 0.26 & 0.24 & 0.23 & 0.23 & 0.017 \\
\hline 37 & $\mathrm{~L}$ & Capillary & $24 \mathrm{BL}$ & 0.32 & 0.32 & 0.34 & 0.33 & 0.33 & 0.34 & 0.33 & 0.009 \\
\hline 38 & $\mathrm{R}$ & Packed & $25 \mathrm{R}$ & 0.35 & 0.34 & 0.43 & 0.41 & 0.38 & 0.32 & 0.37 & 0.043 \\
\hline 39 & $\mathrm{R}$ & Capillary & 26AR & 0.33 & 0.44 & 0.31 & 0.27 & 0.25 & 0.29 & 0.31 & 0.066 \\
\hline 40 & $\mathrm{R}$ & Capillary & 26BR & 0.40 & 0.39 & 0.36 & 0.30 & 0.44 & 0.38 & 0.38 & 0.044 \\
\hline 41 & $\mathrm{~L}$ & Capillary & $27 \mathrm{~L}$ & 0.32 & 0.23 & 0.18 & 0.07 & 0.19 & 0.17 & 0.19 & 0.082 \\
\hline 42 & $\mathrm{~L}$ & Packed & $28 \mathrm{~L}$ & 0.19 & 0.38 & 0.22 & 0.40 & 0.37 & 0.44 & 0.33 & 0.103 \\
\hline 43 & $\mathrm{~L}$ & Packed & $29 \mathrm{~L}$ & 0.17 & 0.28 & 0.41 & 0.33 & 0.13 & 0.30 & 0.27 & 0.104 \\
\hline 44 & $\mathrm{R}$ & Packed & $30 \mathrm{R}$ & 0.42 & 0.42 & 0.30 & 0.27 & 0.36 & 0.31 & 0.35 & 0.064 \\
\hline 45 & $\mathrm{~L}$ & Packed & 31L & 0.14 & 0.13 & 0.77 & 0.65 & 0.00 & 0.71 & 0.40 & 0.345 \\
\hline 46 & $\mathrm{R}$ & Capillary & $32 \mathrm{AR}$ & 0.21 & 0.22 & 0.16 & 0.20 & 0.06 & 0.35 & 0.20 & 0.093 \\
\hline 47 & $\mathrm{R}$ & Capillary & 32BR & 0.22 & 0.18 & 0.25 & 0.27 & 0.33 & 0.48 & 0.29 & 0.106 \\
\hline 48 & $\mathrm{R}$ & Capillary & $33 R$ & 0.21 & 0.28 & 0.25 & 0.21 & 0.30 & 0.21 & 0.24 & 0.041 \\
\hline 49 & $\mathrm{R}$ & Packed & $34 \mathrm{R}$ & 0.54 & 0.39 & 0.35 & 0.39 & 0.40 & 0.28 & 0.39 & 0.084 \\
\hline 50 & $\mathrm{~L}$ & Packed & $35 \mathrm{~L}$ & 0.92 & 0.26 & 1.08 & 0.84 & 0.35 & 0.25 & 0.62 & 0.371 \\
\hline 51 & $\mathrm{R}$ & Capillary & 36AR & 0.56 & 0.52 & 0.48 & 0.55 & 0.53 & 0.50 & 0.52 & 0.030 \\
\hline 52 & $\mathrm{R}$ & Capillary & 36BR & 0.48 & 0.53 & 0.51 & 0.50 & 0.55 & 0.53 & 0.52 & 0.025 \\
\hline 53 & $\mathrm{R}$ & Capillary & $37 A R$ & 0.17 & 0.33 & 0.04 & 0.19 & 0.18 & 0.27 & 0.20 & 0.098 \\
\hline 54 & $\mathrm{~L}$ & Capillary & $37 \mathrm{BL}$ & 0.12 & 0.32 & 0.64 & 0.49 & 0.41 & 0.52 & 0.42 & 0.181 \\
\hline 55 & $\mathrm{R}$ & Packed & $38 \mathrm{R}$ & 0.27 & 0.25 & 0.32 & 0.28 & 0.26 & 0.29 & 0.28 & 0.024 \\
\hline 56 & $\mathrm{R}$ & Packed & $39 R$ & 0.46 & 0.26 & 0.37 & 0.31 & 0.36 & 0.32 & 0.35 & 0.069 \\
\hline
\end{tabular}


Table B2. Continued.

\begin{tabular}{|c|c|c|c|c|c|c|c|c|c|c|c|}
\hline \multirow{2}{*}{ No. } & \multirow{2}{*}{$\begin{array}{l}\text { Smoking } \\
\text { machine }\end{array}$} & \multirow{2}{*}{$\begin{array}{c}\text { GC column } \\
\text { type }\end{array}$} & \multirow{2}{*}{$\begin{array}{l}\text { Lab. } \\
\text { code }\end{array}$} & \multicolumn{6}{|c|}{ No. of run } & \multirow{2}{*}{ Mean } & \multirow{2}{*}{ SD } \\
\hline & & & & 1 & 2 & 3 & 4 & 5 & 6 & & \\
\hline 57 & $\mathrm{R}$ & Packed & $40 R$ & 0.30 & 0.32 & 0.40 & 0.37 & 0.51 & 0.34 & 0.37 & 0.076 \\
\hline 58 & $\mathrm{R}$ & Capillary & $41 \mathrm{R}$ & 0.26 & 0.24 & 0.25 & 0.25 & 0.24 & 0.24 & 0.25 & 0.010 \\
\hline 59 & $\mathrm{~L}$ & Capillary & $42 \mathrm{~L}$ & 0.24 & 0.20 & 0.32 & 0.23 & 0.28 & 0.29 & 0.26 & 0.044 \\
\hline 60 & $\mathrm{~L}$ & Packed & $43 \mathrm{AL}$ & 0.65 & 0.40 & 0.35 & 0.38 & 0.37 & 0.47 & 0.44 & 0.112 \\
\hline 61 & $\mathrm{~L}$ & Packed & $43 B \mathrm{~B}$ & 0.83 & 0.40 & 0.36 & 0.42 & 0.40 & 0.41 & 0.47 & 0.178 \\
\hline 62 & $\mathrm{~L}$ & Capillary & $44 \mathrm{AL}$ & 0.28 & 0.08 & 0.42 & 0.40 & 0.44 & 0.01 & 0.27 & 0.186 \\
\hline 63 & $\mathrm{~L}$ & Capillary & 44BL & 0.21 & 0.16 & 0.24 & 0.22 & 0.26 & 0.24 & 0.22 & 0.035 \\
\hline 64 & $\mathrm{R}$ & Packed & $45 R$ & 0.27 & 0.26 & 0.23 & 0.20 & 0.23 & 0.19 & 0.23 & 0.032 \\
\hline 65 & $\mathrm{~L}$ & Packed & $46 \mathrm{~L}$ & 0.00 & 0.05 & 0.14 & 0.24 & 0.28 & 0.11 & 0.14 & 0.108 \\
\hline 66 & $\mathrm{~L}$ & Packed & $47 \mathrm{~L}$ & 0.55 & 0.55 & 0.25 & 0.45 & 0.30 & 0.40 & 0.42 & 0.125 \\
\hline 67 & $\mathrm{~L}$ & Capillary & $48 \mathrm{~L}$ & 0.31 & 0.29 & 0.30 & 0.28 & 0.30 & 0.29 & 0.30 & 0.010 \\
\hline 68 & $\mathrm{R}$ & Packed & $49 R$ & 0.54 & 0.31 & 0.19 & 0.31 & 0.28 & 0.36 & 0.33 & 0.117 \\
\hline 69 & $\mathrm{R}$ & Packed & 50AR & 0.24 & 0.21 & 0.28 & 0.28 & 0.20 & 0.19 & 0.23 & 0.040 \\
\hline 70 & $\mathrm{R}$ & Packed & 50BR & 0.17 & 0.16 & 0.18 & 0.19 & 0.27 & 0.19 & 0.19 & 0.039 \\
\hline 71 & $\mathrm{~L}$ & Packed & $50 \mathrm{CL}$ & 0.22 & 0.24 & 0.23 & 0.32 & 0.37 & 0.14 & 0.25 & 0.081 \\
\hline 72 & $\mathrm{R}$ & Capillary & 51R & 0.44 & 0.42 & 0.41 & 0.35 & 0.31 & 0.44 & 0.40 & 0.053 \\
\hline 73 & $\mathrm{R}$ & Capillary & $52 \mathrm{R}$ & 0.01 & 0.05 & 0.00 & 0.06 & 0.17 & 0.02 & 0.05 & 0.062 \\
\hline 74 & $\mathrm{~L}$ & Packed & $53 \mathrm{~L}$ & 0.25 & 0.29 & 0.24 & 0.25 & 0.30 & 0.25 & 0.26 & 0.025 \\
\hline 75 & $\mathrm{R}$ & Capillary & $54 \mathrm{R}$ & 0.26 & 0.25 & 0.29 & 0.22 & 0.25 & 0.22 & 0.25 & 0.026 \\
\hline 76 & $\mathrm{R}$ & unknown & $55 R$ & 0.56 & 0.56 & 0.38 & 0.38 & 0.19 & 0.38 & 0.41 & 0.139 \\
\hline 77 & $\mathrm{~L}$ & Packed & $56 \mathrm{~L}$ & 1.23 & 0.92 & 2.19 & 2.43 & 1.56 & 2.72 & 1.84 & 0.713 \\
\hline 78 & $\mathrm{R}$ & Packed & 57R & 0.35 & 0.45 & 0.34 & 0.33 & 0.32 & 0.30 & 0.35 & 0.053 \\
\hline 79 & $\mathrm{~L}$ & Packed & $58 \mathrm{~L}$ & 0.21 & 0.39 & 0.13 & 0.25 & 0.23 & 0.16 & 0.23 & 0.091 \\
\hline 80 & $L$ & Packed & $59 \mathrm{~L}$ & 0.25 & 1.20 & 1.15 & 0.41 & 2.09 & 0.87 & 1.00 & 0.660 \\
\hline 81 & $\mathrm{R}$ & Packed & 60AR & 0.33 & 0.30 & 0.28 & 0.26 & 0.25 & 0.35 & 0.30 & 0.039 \\
\hline 82 & $\mathrm{~L}$ & Packed & $60 \mathrm{BL}$ & 0.32 & 0.24 & 0.20 & 0.28 & 0.24 & 0.31 & 0.27 & 0.046 \\
\hline 83 & $\mathrm{R}$ & Packed & $61 \mathrm{R}$ & 0.30 & 0.29 & 0.30 & 0.28 & 0.34 & 0.27 & 0.30 & 0.024 \\
\hline 84 & $\mathrm{R}$ & Capillary & $62 \mathrm{R}$ & 0.30 & 0.12 & 0.26 & 0.25 & 0.46 & 0.47 & 0.31 & 0.134 \\
\hline 85 & $\mathrm{~L}$ & Capillary & $63 \mathrm{~L}$ & 0.35 & 0.34 & 0.31 & 0.35 & 0.33 & 0.34 & 0.34 & 0.015 \\
\hline 86 & $\mathrm{R}$ & Packed & $64 \mathrm{R}$ & 0.16 & 0.12 & 0.21 & 0.29 & 0.31 & 0.23 & 0.22 & 0.073 \\
\hline
\end{tabular}


Table B3. Raw data of water yields for sample C (unit: $\mathrm{mg} / \mathrm{cig}$ ).

\begin{tabular}{|c|c|c|c|c|c|c|c|c|c|c|c|}
\hline \multirow{2}{*}{ No. } & \multirow{2}{*}{$\begin{array}{l}\text { Smoking } \\
\text { machine }\end{array}$} & \multirow{2}{*}{$\begin{array}{l}\text { GC column } \\
\text { type }\end{array}$} & \multirow{2}{*}{$\begin{array}{l}\text { Lab. } \\
\text { code }\end{array}$} & \multicolumn{6}{|c|}{ No. of run } & \multirow{2}{*}{ Mean } & \multirow{2}{*}{ SD } \\
\hline & & & & 1 & 2 & 3 & 4 & 5 & 6 & & \\
\hline 1 & $\mathrm{R}$ & Capillary & $01 R$ & 0.87 & 0.83 & 1.09 & 1.00 & 0.90 & 1.04 & 0.96 & 0.103 \\
\hline 2 & $\mathrm{R}$ & Capillary & $02 \mathrm{R}$ & 1.25 & 1.06 & 0.81 & 0.92 & 1.09 & 0.95 & 1.01 & 0.154 \\
\hline 3 & $\mathrm{~L}$ & Packed & 03AL & 0.46 & 0.49 & 0.50 & 0.45 & 0.41 & 0.38 & 0.45 & 0.046 \\
\hline 4 & $\mathrm{R}$ & Packed & 03BR & 0.50 & 0.68 & 0.49 & 0.68 & 0.50 & 0.42 & 0.55 & 0.111 \\
\hline 5 & $\mathrm{~L}$ & Packed & 04L & 0.72 & 0.62 & 0.66 & 0.63 & 0.74 & 0.78 & 0.69 & 0.065 \\
\hline 6 & L & Packed & $05 \mathrm{~L}$ & 0.60 & 0.69 & 0.68 & 0.63 & 0.76 & 0.71 & 0.68 & 0.057 \\
\hline 7 & $\mathrm{~L}$ & Capillary & 06AL & 0.63 & 0.64 & 0.67 & 0.48 & 0.45 & 0.77 & 0.61 & 0.121 \\
\hline 8 & $\mathrm{~L}$ & Capillary & 06BL & 0.60 & 0.38 & 0.41 & 0.43 & 0.84 & 0.66 & 0.55 & 0.180 \\
\hline 9 & $\mathrm{R}$ & Capillary & 07AR & 1.00 & 0.98 & 1.01 & 0.93 & 0.90 & 0.92 & 0.96 & 0.048 \\
\hline 10 & $\mathrm{R}$ & Capillary & 07BR & 0.97 & 0.96 & 0.87 & 0.91 & 0.91 & 0.91 & 0.92 & 0.036 \\
\hline 11 & $\mathrm{~L}$ & Capillary & 07CL & 0.58 & 0.60 & 0.58 & 0.57 & 0.55 & 0.59 & 0.58 & 0.017 \\
\hline 12 & $\mathrm{R}$ & Capillary & 08R & 0.94 & 0.88 & 0.90 & 0.80 & 0.80 & 0.87 & 0.87 & 0.056 \\
\hline 13 & $\mathrm{R}$ & Capillary & 09R & 0.88 & 0.73 & 0.79 & 0.61 & 0.95 & 0.81 & 0.80 & 0.118 \\
\hline 14 & $\mathrm{R}$ & Capillary & $10 \mathrm{R}$ & 0.92 & 0.88 & 0.80 & 0.91 & 0.86 & 0.81 & 0.86 & 0.051 \\
\hline 15 & $\mathrm{~L}$ & Capillary & $11 \mathrm{~L}$ & 0.39 & 0.53 & 0.57 & 0.27 & 0.56 & 0.61 & 0.49 & 0.131 \\
\hline 16 & $\mathrm{R}$ & Packed & $12 \mathrm{R}$ & 1.12 & 0.91 & 1.10 & 1.04 & 1.01 & 1.14 & 1.05 & 0.085 \\
\hline 17 & $\mathrm{R}$ & Capillary & $13 A R$ & 0.93 & 0.94 & 0.94 & 0.94 & 0.91 & 0.93 & 0.93 & 0.012 \\
\hline 18 & $\mathrm{R}$ & Capillary & 13BR & 0.82 & 0.81 & 0.91 & 0.92 & 0.92 & 0.92 & 0.88 & 0.053 \\
\hline 19 & $\mathrm{R}$ & Packed & $14 \mathrm{R}$ & 0.87 & 0.81 & 0.77 & 0.97 & 0.79 & 0.96 & 0.86 & 0.088 \\
\hline 20 & $\mathrm{R}$ & Capillary & 15AR & 1.01 & 0.93 & 1.01 & 0.88 & 0.99 & 1.01 & 0.97 & 0.055 \\
\hline 21 & $\mathrm{~L}$ & Capillary & $15 B L$ & 0.60 & 0.46 & 0.69 & 0.40 & 0.45 & 0.44 & 0.51 & 0.113 \\
\hline 22 & $\mathrm{R}$ & Packed & $16 \mathrm{R}$ & 0.58 & 0.69 & 0.66 & 0.79 & 0.72 & 0.97 & 0.74 & 0.134 \\
\hline 23 & $\mathrm{R}$ & Packed & 17AR & 0.70 & 0.76 & 0.96 & 0.71 & 0.78 & 0.68 & 0.77 & 0.103 \\
\hline 24 & $\mathrm{~L}$ & Packed & 17BL & 0.62 & 0.57 & 0.55 & 0.47 & 0.52 & 0.42 & 0.53 & 0.072 \\
\hline 25 & $\mathrm{R}$ & Capillary & 18AR & 0.75 & 0.90 & 0.89 & 0.88 & 1.00 & 0.88 & 0.88 & 0.078 \\
\hline 26 & $\mathrm{~L}$ & Capillary & 18BL & 0.66 & 0.65 & 0.90 & 0.67 & 0.65 & 0.40 & 0.66 & 0.158 \\
\hline 27 & $\mathrm{~L}$ & Capillary & $19 A L$ & 0.56 & 0.58 & 0.64 & 0.64 & 0.68 & 0.61 & 0.62 & 0.044 \\
\hline 28 & $\mathrm{R}$ & Capillary & 19BR & 0.98 & 0.81 & 0.93 & 0.91 & 0.90 & 0.84 & 0.90 & 0.061 \\
\hline 29 & $\mathrm{~L}$ & Capillary & $19 C L$ & 0.66 & 0.67 & 0.64 & 0.70 & 0.66 & 0.70 & 0.67 & 0.024 \\
\hline 30 & $\mathrm{R}$ & Capillary & 19DR & 0.81 & 0.82 & 0.96 & 0.83 & 0.74 & 0.76 & 0.82 & 0.078 \\
\hline 31 & $\mathrm{~L}$ & Packed & 19EL & 0.56 & 0.52 & 0.56 & 0.51 & 0.53 & 0.60 & 0.55 & 0.033 \\
\hline 32 & L & Packed & $20 \mathrm{~L}$ & 0.71 & 0.63 & 0.59 & 0.73 & 0.55 & 0.58 & 0.63 & 0.073 \\
\hline 33 & $\mathrm{~L}$ & Capillary & $21 \mathrm{~L}$ & 0.78 & 0.76 & 0.77 & 0.79 & 0.78 & 0.76 & 0.77 & 0.012 \\
\hline 34 & $\mathrm{R}$ & Capillary & $22 \mathrm{R}$ & 0.71 & 0.77 & 0.78 & 0.84 & 1.03 & 1.09 & 0.87 & 0.156 \\
\hline 35 & $\mathrm{R}$ & Capillary & $23 R$ & 0.90 & 0.90 & 0.61 & 0.68 & 0.81 & 0.89 & 0.80 & 0.125 \\
\hline 36 & $\mathrm{R}$ & Capillary & $24 \mathrm{AR}$ & 0.75 & 0.73 & 0.72 & 0.72 & 0.72 & 0.71 & 0.73 & 0.014 \\
\hline 37 & $\mathrm{~L}$ & Capillary & $24 B L$ & 0.64 & 0.61 & 0.64 & 0.66 & 0.64 & 0.63 & 0.64 & 0.016 \\
\hline 38 & $\mathrm{R}$ & Packed & $25 R$ & 1.20 & 1.12 & 0.87 & 1.04 & 0.96 & 0.99 & 1.03 & 0.116 \\
\hline 39 & $\mathrm{R}$ & Capillary & 26AR & 0.89 & 0.91 & 0.99 & 0.86 & 0.91 & 0.88 & 0.91 & 0.045 \\
\hline 40 & $\mathrm{R}$ & Capillary & 26BR & 1.08 & 1.02 & 1.13 & 0.97 & 1.10 & 1.13 & 1.07 & 0.063 \\
\hline 41 & $\mathrm{~L}$ & Capillary & $27 \mathrm{~L}$ & 0.64 & 0.60 & 0.69 & 0.52 & 0.47 & 0.49 & 0.57 & 0.088 \\
\hline 42 & $\mathrm{~L}$ & Packed & $28 \mathrm{~L}$ & 0.51 & 0.70 & 0.85 & 0.79 & 0.64 & 0.72 & 0.70 & 0.119 \\
\hline 43 & $\mathrm{~L}$ & Packed & $29 \mathrm{~L}$ & 0.67 & 0.63 & 0.72 & 0.83 & 0.71 & 0.64 & 0.70 & 0.073 \\
\hline 44 & $\mathrm{R}$ & Packed & $30 R$ & 1.12 & 1.11 & 1.01 & 0.95 & 1.02 & 0.94 & 1.03 & 0.077 \\
\hline 45 & $\mathrm{~L}$ & Packed & $31 \mathrm{~L}$ & 0.71 & 0.52 & 0.67 & 0.14 & 0.60 & 0.67 & 0.55 & 0.213 \\
\hline 46 & $\mathrm{R}$ & Capillary & $32 \mathrm{AR}$ & 0.72 & 0.80 & 0.77 & 0.94 & 0.71 & 0.93 & 0.81 & 0.102 \\
\hline 47 & $\mathrm{R}$ & Capillary & 32BR & 1.02 & 1.00 & 0.84 & 0.95 & 0.76 & 0.68 & 0.88 & 0.138 \\
\hline 48 & $\mathrm{R}$ & Capillary & $33 R$ & 0.72 & 0.81 & 0.76 & 0.71 & 0.60 & 0.61 & 0.70 & 0.085 \\
\hline 49 & $\mathrm{R}$ & Packed & $34 \mathrm{R}$ & 1.38 & 1.29 & 1.33 & 1.08 & 1.13 & 1.07 & 1.21 & 0.134 \\
\hline 50 & $\mathrm{~L}$ & Packed & $35 \mathrm{~L}$ & 0.89 & 0.76 & 1.17 & 1.04 & 0.61 & 0.59 & 0.84 & 0.234 \\
\hline 51 & $\mathrm{R}$ & Capillary & 36AR & 0.97 & 0.86 & 0.94 & 0.91 & 0.82 & 0.86 & 0.89 & 0.056 \\
\hline 52 & $\mathrm{R}$ & Capillary & 36BR & 0.95 & 0.93 & 0.98 & 0.93 & 0.97 & 0.88 & 0.94 & 0.036 \\
\hline 53 & $\mathrm{R}$ & Capillary & $37 A R$ & 0.82 & 0.62 & 0.60 & 0.48 & 0.67 & 1.00 & 0.70 & 0.183 \\
\hline 54 & $\mathrm{~L}$ & Capillary & 37BL & 0.66 & 0.83 & 1.05 & 0.68 & 0.84 & 1.05 & 0.85 & 0.171 \\
\hline 55 & $\mathrm{R}$ & Packed & $38 \mathrm{R}$ & 0.88 & 0.79 & 0.96 & 0.81 & 0.83 & 0.89 & 0.86 & 0.060 \\
\hline 56 & $\mathrm{R}$ & Packed & $39 R$ & 1.10 & 0.85 & 1.28 & 0.98 & 1.02 & 0.94 & 1.03 & 0.150 \\
\hline
\end{tabular}


Table B3. Continued.

\begin{tabular}{|c|c|c|c|c|c|c|c|c|c|c|c|}
\hline \multirow{2}{*}{ No. } & \multirow{2}{*}{$\begin{array}{l}\text { Smoking } \\
\text { machine }\end{array}$} & \multirow{2}{*}{$\begin{array}{c}\text { GC column } \\
\text { type }\end{array}$} & \multirow{2}{*}{$\begin{array}{l}\text { Lab. } \\
\text { code }\end{array}$} & \multicolumn{6}{|c|}{ No. of run } & \multirow{2}{*}{ Mean } & \multirow{2}{*}{ SD } \\
\hline & & & & 1 & 2 & 3 & 4 & 5 & 6 & & \\
\hline 57 & $\mathrm{R}$ & Packed & $40 R$ & 1.09 & 0.93 & 1.23 & 1.19 & 1.84 & 1.53 & 1.30 & 0.329 \\
\hline 58 & $\mathrm{R}$ & Capillary & $41 \mathrm{R}$ & 0.92 & 0.95 & 0.73 & 0.73 & 0.88 & 0.75 & 0.83 & 0.100 \\
\hline 59 & $\mathrm{~L}$ & Capillary & $42 \mathrm{~L}$ & 0.60 & 0.56 & 0.50 & 0.60 & 0.53 & 0.64 & 0.57 & 0.052 \\
\hline 60 & $\mathrm{~L}$ & Packed & $43 A L$ & 0.79 & 0.75 & 0.74 & 0.74 & 0.70 & 0.78 & 0.75 & 0.032 \\
\hline 61 & $\mathrm{~L}$ & Packed & $43 B L$ & 0.70 & 0.72 & 0.73 & 0.74 & 0.74 & 0.73 & 0.73 & 0.015 \\
\hline 62 & $\mathrm{~L}$ & Capillary & $44 \mathrm{AL}$ & 0.60 & 0.31 & 0.70 & 0.67 & 0.43 & 0.58 & 0.55 & 0.150 \\
\hline 63 & $\mathrm{~L}$ & Capillary & 44BL & 0.49 & 0.68 & 0.46 & 0.61 & 0.84 & 0.58 & 0.61 & 0.138 \\
\hline 64 & $\mathrm{R}$ & Packed & $45 \mathrm{R}$ & 0.69 & 0.68 & 0.85 & 0.67 & 0.64 & 0.69 & 0.70 & 0.074 \\
\hline 65 & $\mathrm{~L}$ & Packed & $46 \mathrm{~L}$ & 0.46 & 0.43 & 0.44 & 0.66 & 0.46 & 0.52 & 0.50 & 0.087 \\
\hline 66 & $\mathrm{~L}$ & Packed & $47 \mathrm{~L}$ & 0.88 & 0.90 & 0.83 & 0.68 & 0.68 & 0.73 & 0.78 & 0.099 \\
\hline 67 & $\mathrm{~L}$ & Capillary & $48 \mathrm{~L}$ & 0.77 & 0.79 & 0.78 & 0.78 & 0.74 & 0.76 & 0.77 & 0.018 \\
\hline 68 & $\mathrm{R}$ & Packed & $49 \mathrm{R}$ & 1.10 & 0.85 & 1.14 & 1.10 & 1.05 & 1.08 & 1.05 & 0.104 \\
\hline 69 & $\mathrm{R}$ & Packed & 50AR & 0.78 & 0.79 & 0.81 & 0.78 & 0.77 & 0.71 & 0.77 & 0.034 \\
\hline 70 & $\mathrm{R}$ & Packed & 50BR & 0.78 & 0.64 & 0.82 & 0.65 & 0.81 & 0.81 & 0.75 & 0.084 \\
\hline 71 & $\mathrm{~L}$ & Packed & $50 C L$ & 0.61 & 0.54 & 0.61 & 0.62 & 0.43 & 0.52 & 0.56 & 0.074 \\
\hline 72 & $\mathrm{R}$ & Capillary & 51R & 0.92 & 0.99 & 0.79 & 0.97 & 1.11 & 1.11 & 0.98 & 0.121 \\
\hline 73 & $\mathrm{R}$ & Capillary & $52 \mathrm{R}$ & 0.68 & 0.51 & 0.48 & 0.68 & 0.67 & 0.81 & 0.64 & 0.123 \\
\hline 74 & $\mathrm{~L}$ & Packed & $53 \mathrm{~L}$ & 0.73 & 0.75 & 0.76 & 0.75 & 0.75 & 0.74 & 0.75 & 0.010 \\
\hline 75 & $\mathrm{R}$ & Capillary & $54 \mathrm{R}$ & 0.92 & 0.68 & 0.81 & 0.80 & 0.73 & 0.89 & 0.81 & 0.091 \\
\hline 76 & $\mathrm{R}$ & unknown & $55 \mathrm{R}$ & 0.75 & 0.94 & 0.94 & 1.13 & 0.94 & 0.94 & 0.94 & 0.120 \\
\hline 77 & $\mathrm{~L}$ & Packed & $56 \mathrm{~L}$ & 1.40 & 1.45 & 2.24 & 2.81 & 3.22 & 3.68 & 2.47 & 0.936 \\
\hline 78 & $\mathrm{R}$ & Packed & 57R & 0.92 & 0.98 & 0.99 & 0.91 & 1.00 & 1.02 & 0.97 & 0.045 \\
\hline 79 & $\mathrm{~L}$ & Packed & $58 \mathrm{~L}$ & 0.53 & 0.57 & 0.50 & 0.58 & 0.48 & 0.45 & 0.52 & 0.051 \\
\hline 80 & $\mathrm{~L}$ & Packed & $59 \mathrm{~L}$ & 0.62 & 1.55 & 0.88 & 1.34 & 0.75 & 2.32 & 1.24 & 0.637 \\
\hline 81 & $\mathrm{R}$ & Packed & 60AR & 0.86 & 1.02 & 0.90 & 0.75 & 0.81 & 0.77 & 0.85 & 0.099 \\
\hline 82 & $\mathrm{~L}$ & Packed & $60 \mathrm{BL}$ & 0.66 & 0.55 & 0.72 & 0.65 & 0.60 & 0.77 & 0.66 & 0.079 \\
\hline 83 & $\mathrm{R}$ & Packed & $61 \mathrm{R}$ & 0.72 & 0.73 & 0.70 & 0.70 & 0.69 & 0.69 & 0.71 & 0.016 \\
\hline 84 & $\mathrm{R}$ & Capillary & $62 \mathrm{R}$ & 0.87 & 0.82 & 1.13 & 1.08 & 1.24 & 1.10 & 1.04 & 0.162 \\
\hline 85 & $\mathrm{~L}$ & Capillary & $63 \mathrm{~L}$ & 0.74 & 0.75 & 0.70 & 0.79 & 0.70 & 0.71 & 0.73 & 0.035 \\
\hline 86 & $\mathrm{R}$ & Packed & $64 \mathrm{R}$ & 0.43 & 0.63 & 0.50 & 0.61 & 0.69 & 0.67 & 0.59 & 0.102 \\
\hline
\end{tabular}


Table B4. Raw data of water yields for sample D (unit: $\mathrm{mg} / \mathrm{cig}$ ).

\begin{tabular}{|c|c|c|c|c|c|c|c|c|c|c|c|}
\hline \multirow{2}{*}{ No. } & \multirow{2}{*}{$\begin{array}{l}\text { Smoking } \\
\text { machine }\end{array}$} & \multirow{2}{*}{$\begin{array}{l}\text { GC column } \\
\text { type }\end{array}$} & \multirow{2}{*}{$\begin{array}{l}\text { Lab. } \\
\text { code }\end{array}$} & \multicolumn{6}{|c|}{ No. of run } & \multirow{2}{*}{ Mean } & \multirow{2}{*}{ SD } \\
\hline & & & & 1 & 2 & 3 & 4 & 5 & 6 & & \\
\hline 1 & $\mathrm{R}$ & Capillary & $01 R$ & 1.58 & 1.59 & 1.79 & 1.73 & 1.75 & 1.70 & 1.69 & 0.086 \\
\hline 2 & $\mathrm{R}$ & Capillary & $02 R$ & 2.16 & 2.03 & 1.76 & 1.66 & 2.02 & - & 1.93 & 0.207 \\
\hline 3 & $\mathrm{~L}$ & Packed & 03AL & 1.01 & 1.00 & 1.08 & 1.05 & 1.09 & 0.95 & 1.03 & 0.053 \\
\hline 4 & $\mathrm{R}$ & Packed & 03BR & 1.20 & 1.48 & 1.06 & 1.36 & 1.18 & 1.07 & 1.22 & 0.167 \\
\hline 5 & $\mathrm{~L}$ & Packed & 04L & 1.31 & 1.33 & 1.24 & 1.42 & 1.31 & 1.45 & 1.34 & 0.078 \\
\hline 6 & L & Packed & $05 \mathrm{~L}$ & 1.51 & 1.48 & 1.47 & 1.54 & 1.68 & 1.55 & 1.54 & 0.076 \\
\hline 7 & $\mathrm{~L}$ & Capillary & 06AL & 1.28 & 1.25 & 1.49 & 1.80 & 1.22 & 1.24 & 1.38 & 0.228 \\
\hline 8 & $\mathrm{~L}$ & Capillary & 06BL & 1.19 & 1.07 & 0.73 & 0.89 & 1.28 & 0.83 & 1.00 & 0.216 \\
\hline 9 & $\mathrm{R}$ & Capillary & 07AR & 2.00 & 1.84 & 2.05 & 1.86 & 1.80 & 1.88 & 1.90 & 0.097 \\
\hline 10 & $\mathrm{R}$ & Capillary & 07BR & 1.95 & 2.00 & 1.71 & 1.77 & 1.80 & 1.75 & 1.83 & 0.116 \\
\hline 11 & $\mathrm{~L}$ & Capillary & $07 \mathrm{CL}$ & 1.25 & 1.19 & 1.44 & 1.32 & 1.15 & 1.00 & 1.23 & 0.151 \\
\hline 12 & $\mathrm{R}$ & Capillary & 08R & 1.70 & 1.69 & 1.75 & 1.79 & 1.67 & 1.53 & 1.69 & 0.089 \\
\hline 13 & $\mathrm{R}$ & Capillary & 09R & 1.62 & 1.46 & 1.61 & 1.47 & 1.69 & 1.43 & 1.55 & 0.107 \\
\hline 14 & $\mathrm{R}$ & Capillary & $10 R$ & 2.01 & 2.11 & 2.01 & 1.97 & 2.04 & 2.02 & 2.02 & 0.049 \\
\hline 15 & $\mathrm{~L}$ & Capillary & $11 \mathrm{~L}$ & 1.09 & 1.14 & 1.08 & 1.38 & 1.19 & 1.35 & 1.21 & 0.130 \\
\hline 16 & $\mathrm{R}$ & Packed & $12 \mathrm{R}$ & 1.71 & 1.75 & 1.71 & 1.76 & 1.74 & 1.67 & 1.72 & 0.033 \\
\hline 17 & $\mathrm{R}$ & Capillary & $13 A R$ & 1.55 & 1.50 & 1.36 & 1.28 & 1.58 & 1.45 & 1.45 & 0.115 \\
\hline 18 & $\mathrm{R}$ & Capillary & 13BR & 1.62 & 1.42 & 1.55 & 1.46 & 1.67 & 1.51 & 1.54 & 0.095 \\
\hline 19 & $\mathrm{R}$ & Packed & $14 \mathrm{R}$ & 1.81 & 1.74 & 1.39 & 1.80 & 1.49 & 1.77 & 1.67 & 0.179 \\
\hline 20 & $\mathrm{R}$ & Capillary & 15AR & 1.74 & 1.67 & 1.64 & 1.70 & 1.67 & 1.72 & 1.69 & 0.037 \\
\hline 21 & $\mathrm{~L}$ & Capillary & $15 B L$ & 1.12 & 1.05 & 1.29 & 1.00 & 1.31 & 1.01 & 1.13 & 0.138 \\
\hline 22 & $\mathrm{R}$ & Packed & $16 \mathrm{R}$ & 1.45 & 1.44 & 1.53 & 1.70 & 1.45 & 1.65 & 1.54 & 0.113 \\
\hline 23 & $\mathrm{R}$ & Packed & 17AR & 1.58 & 1.54 & 1.71 & 1.33 & 1.60 & 1.37 & 1.52 & 0.145 \\
\hline 24 & $\mathrm{~L}$ & Packed & 17BL & 1.25 & 1.18 & 1.25 & 1.22 & 1.14 & 0.88 & 1.15 & 0.141 \\
\hline 25 & $\mathrm{R}$ & Capillary & 18AR & 1.52 & 1.64 & 1.51 & 1.68 & 1.66 & 1.76 & 1.63 & 0.096 \\
\hline 26 & $\mathrm{~L}$ & Capillary & 18BL & 1.57 & 1.17 & 1.65 & 1.46 & 1.54 & 1.28 & 1.45 & 0.184 \\
\hline 27 & $\mathrm{~L}$ & Capillary & $19 A L$ & 1.38 & 1.36 & 1.51 & 1.56 & 1.50 & 1.48 & 1.47 & 0.078 \\
\hline 28 & $\mathrm{R}$ & Capillary & 19BR & 1.73 & 1.62 & 1.79 & 1.71 & 1.69 & 1.59 & 1.69 & 0.073 \\
\hline 29 & $\mathrm{~L}$ & Capillary & $19 C L$ & 1.53 & 1.54 & 1.38 & 1.36 & 1.44 & 1.55 & 1.47 & 0.085 \\
\hline 30 & $\mathrm{R}$ & Capillary & 19DR & 1.54 & 1.40 & 1.56 & 1.48 & 1.48 & 1.34 & 1.47 & 0.083 \\
\hline 31 & $\mathrm{~L}$ & Packed & 19EL & 1.38 & 1.36 & 1.39 & 1.34 & 1.39 & 1.32 & 1.36 & 0.029 \\
\hline 32 & L & Packed & $20 \mathrm{~L}$ & 1.38 & 1.39 & 1.49 & 1.50 & 1.41 & 1.50 & 1.45 & 0.058 \\
\hline 33 & $\mathrm{~L}$ & Capillary & $21 \mathrm{~L}$ & 1.47 & 1.45 & 1.46 & 1.45 & 1.45 & 1.44 & 1.45 & 0.010 \\
\hline 34 & $\mathrm{R}$ & Capillary & $22 \mathrm{R}$ & 1.52 & 1.65 & 1.82 & 1.82 & 1.94 & 2.07 & 1.80 & 0.197 \\
\hline 35 & $\mathrm{R}$ & Capillary & $23 R$ & 1.49 & 1.50 & 1.34 & 1.41 & 1.50 & 1.52 & 1.46 & 0.072 \\
\hline 36 & $\mathrm{R}$ & Capillary & $24 \mathrm{AR}$ & 1.51 & 1.42 & 1.20 & 1.53 & 1.46 & 1.46 & 1.43 & 0.119 \\
\hline 37 & $\mathrm{~L}$ & Capillary & $24 B L$ & 1.56 & 1.34 & 1.24 & 1.27 & 1.34 & 1.50 & 1.38 & 0.128 \\
\hline 38 & $\mathrm{R}$ & Packed & $25 R$ & 2.16 & 2.03 & 2.02 & 1.96 & 1.80 & 1.69 & 1.94 & 0.170 \\
\hline 39 & $\mathrm{R}$ & Capillary & 26AR & 2.00 & 1.60 & 2.15 & 2.16 & 1.72 & 1.90 & 1.92 & 0.227 \\
\hline 40 & $\mathrm{R}$ & Capillary & 26BR & 2.12 & 1.84 & 2.19 & 1.95 & 2.10 & 1.98 & 2.03 & 0.130 \\
\hline 41 & $\mathrm{~L}$ & Capillary & $27 \mathrm{~L}$ & 1.32 & 1.36 & 1.37 & 1.08 & 1.17 & 0.93 & 1.21 & 0.177 \\
\hline 42 & $\mathrm{~L}$ & Packed & $28 \mathrm{~L}$ & 1.33 & 1.57 & 1.65 & 1.76 & 1.58 & 1.43 & 1.55 & 0.154 \\
\hline 43 & $\mathrm{~L}$ & Packed & $29 \mathrm{~L}$ & 1.06 & 1.23 & 1.39 & 1.78 & 1.37 & 1.63 & 1.41 & 0.262 \\
\hline 44 & $\mathrm{R}$ & Packed & $30 \mathrm{R}$ & 2.21 & 2.04 & 1.98 & 1.84 & 2.07 & 2.03 & 2.03 & 0.121 \\
\hline 45 & $\mathrm{~L}$ & Packed & 31L & 1.56 & 1.08 & 1.31 & 1.55 & 1.13 & 1.34 & 1.33 & 0.202 \\
\hline 46 & $\mathrm{R}$ & Capillary & $32 \mathrm{AR}$ & 1.70 & 1.62 & 1.69 & 1.60 & 1.52 & 1.51 & 1.61 & 0.083 \\
\hline 47 & $\mathrm{R}$ & Capillary & 32BR & 1.94 & 1.80 & 1.59 & 1.72 & 1.68 & 1.68 & 1.73 & 0.120 \\
\hline 48 & $\mathrm{R}$ & Capillary & $33 \mathrm{R}$ & 1.25 & 1.50 & 1.55 & 1.41 & 1.15 & 1.29 & 1.36 & 0.155 \\
\hline 49 & $\mathrm{R}$ & Packed & $34 \mathrm{R}$ & 2.61 & 2.50 & 2.17 & 2.15 & 2.16 & 1.97 & 2.26 & 0.244 \\
\hline 50 & $\mathrm{~L}$ & Packed & $35 \mathrm{~L}$ & 1.90 & 1.85 & 2.03 & 1.82 & 1.57 & 1.31 & 1.75 & 0.261 \\
\hline 51 & $\mathrm{R}$ & Capillary & 36AR & 1.39 & 1.33 & 1.36 & 1.31 & 1.46 & 1.36 & 1.37 & 0.053 \\
\hline 52 & $\mathrm{R}$ & Capillary & 36BR & 1.45 & 1.36 & 1.41 & 1.51 & 1.55 & 1.48 & 1.46 & 0.069 \\
\hline 53 & $\mathrm{R}$ & Capillary & $37 A R$ & 1.70 & 1.59 & 1.55 & 1.13 & 1.46 & 1.79 & 1.53 & 0.231 \\
\hline 54 & $\mathrm{~L}$ & Capillary & 37BL & 1.11 & 1.29 & 1.36 & 1.31 & 1.17 & 1.62 & 1.31 & 0.178 \\
\hline 55 & $\mathrm{R}$ & Packed & $38 \mathrm{R}$ & 1.65 & 1.63 & 1.73 & 1.91 & 1.73 & 1.74 & 1.73 & 0.100 \\
\hline 56 & $\mathrm{R}$ & Packed & $39 R$ & 1.88 & 1.67 & 2.16 & 2.10 & 1.96 & 1.70 & 1.91 & 0.203 \\
\hline
\end{tabular}


Table B4. Continued.

\begin{tabular}{|c|c|c|c|c|c|c|c|c|c|c|c|}
\hline \multirow{2}{*}{ No. } & \multirow{2}{*}{$\begin{array}{l}\text { Smoking } \\
\text { machine }\end{array}$} & \multirow{2}{*}{$\begin{array}{c}\text { GC column } \\
\text { type }\end{array}$} & \multirow{2}{*}{$\begin{array}{l}\text { Lab. } \\
\text { code }\end{array}$} & \multicolumn{6}{|c|}{ No. of run } & \multirow{2}{*}{ Mean } & \multirow{2}{*}{ SD } \\
\hline & & & & 1 & 2 & 3 & 4 & 5 & 6 & & \\
\hline 57 & $\mathrm{R}$ & Packed & $40 R$ & 2.13 & 2.15 & 2.44 & 2.37 & 2.84 & 2.70 & 2.44 & 0.287 \\
\hline 58 & $\mathrm{R}$ & Capillary & $41 \mathrm{R}$ & 1.64 & 1.40 & 1.36 & 1.29 & 1.41 & 1.43 & 1.42 & 0.117 \\
\hline 59 & $\mathrm{~L}$ & Capillary & $42 \mathrm{~L}$ & 1.14 & 1.14 & 1.20 & 1.21 & 1.20 & 1.24 & 1.19 & 0.040 \\
\hline 60 & $\mathrm{~L}$ & Packed & $43 A L$ & 1.45 & 1.25 & 1.36 & 1.34 & 1.34 & 1.43 & 1.36 & 0.072 \\
\hline 61 & $\mathrm{~L}$ & Packed & 43BL & 1.40 & 1.28 & 1.36 & 1.28 & 1.44 & 1.35 & 1.35 & 0.064 \\
\hline 62 & $L$ & Capillary & $44 \mathrm{AL}$ & 1.27 & 1.14 & 1.50 & 1.43 & 1.25 & 1.13 & 1.29 & 0.151 \\
\hline 63 & $L$ & Capillary & $44 \mathrm{BL}$ & 1.50 & 1.57 & 1.29 & 1.21 & 1.09 & 1.46 & 1.35 & 0.186 \\
\hline 64 & $\mathrm{R}$ & Packed & $45 \mathrm{R}$ & 1.84 & 1.41 & 1.74 & 1.49 & 1.49 & 1.52 & 1.58 & 0.168 \\
\hline 65 & $\mathrm{~L}$ & Packed & $46 \mathrm{~L}$ & 1.01 & 0.87 & 1.05 & 0.94 & 1.24 & 1.06 & 1.03 & 0.126 \\
\hline 66 & $L$ & Packed & $47 \mathrm{~L}$ & 1.63 & 1.50 & 1.75 & 1.30 & 1.70 & 1.43 & 1.55 & 0.172 \\
\hline 67 & $L$ & Capillary & $48 \mathrm{~L}$ & 1.27 & 1.33 & 1.32 & 1.30 & 1.33 & 1.24 & 1.30 & 0.037 \\
\hline 68 & $\mathrm{R}$ & Packed & $49 \mathrm{R}$ & 1.94 & 1.84 & 1.95 & 1.76 & 1.93 & 1.69 & 1.85 & 0.108 \\
\hline 69 & $\mathrm{R}$ & Packed & 50AR & 1.70 & 1.70 & 1.66 & 1.77 & 1.52 & 1.43 & 1.63 & 0.128 \\
\hline 70 & $\mathrm{R}$ & Packed & 50BR & 1.60 & 1.54 & 1.72 & 1.76 & 1.69 & 1.61 & 1.65 & 0.083 \\
\hline 71 & $\mathrm{~L}$ & Packed & $50 \mathrm{CL}$ & 1.40 & 1.32 & 1.40 & 1.27 & 1.55 & 1.33 & 1.38 & 0.098 \\
\hline 72 & $\mathrm{R}$ & Capillary & $51 \mathrm{R}$ & 1.98 & 2.02 & 1.85 & 2.08 & 1.99 & 1.75 & 1.95 & 0.122 \\
\hline 73 & $\mathrm{R}$ & Capillary & $52 \mathrm{R}$ & 1.66 & 1.72 & 1.71 & 1.76 & 1.75 & 2.12 & 1.79 & 0.167 \\
\hline 74 & $\mathrm{~L}$ & Packed & $53 \mathrm{~L}$ & 1.59 & 1.61 & 1.66 & 1.63 & 1.46 & 1.62 & 1.60 & 0.070 \\
\hline 75 & $\mathrm{R}$ & Capillary & $54 \mathrm{R}$ & 1.44 & 1.53 & 1.55 & 1.35 & 1.60 & 1.53 & 1.50 & 0.090 \\
\hline 76 & $\mathrm{R}$ & unknown & $55 \mathrm{R}$ & 1.31 & 1.50 & 1.31 & 1.13 & 0.94 & 1.31 & 1.25 & 0.192 \\
\hline 77 & $\mathrm{~L}$ & Packed & $56 \mathrm{~L}$ & 2.43 & 2.72 & 3.91 & 5.00 & 4.11 & 4.76 & 3.82 & 1.050 \\
\hline 78 & $\mathrm{R}$ & Packed & 57R & 2.00 & 2.13 & 1.99 & 2.06 & 1.83 & 1.93 & 1.99 & 0.104 \\
\hline 79 & $\mathrm{~L}$ & Packed & $58 \mathrm{~L}$ & 1.19 & 1.32 & 1.04 & 1.33 & 1.28 & 1.16 & 1.22 & 0.112 \\
\hline 80 & $\mathrm{~L}$ & Packed & $59 \mathrm{~L}$ & 1.22 & 1.99 & 2.13 & 2.47 & 1.64 & 1.29 & 1.79 & 0.493 \\
\hline 81 & $\mathrm{R}$ & Packed & 60AR & 1.45 & 1.64 & 1.55 & 1.53 & 1.69 & 1.60 & 1.58 & 0.085 \\
\hline 82 & $\mathrm{~L}$ & Packed & $60 \mathrm{BL}$ & 1.69 & 1.74 & 1.68 & 1.49 & 1.46 & 1.62 & 1.61 & 0.114 \\
\hline 83 & $\mathrm{R}$ & Packed & $61 \mathrm{R}$ & 1.00 & 1.02 & 1.00 & 0.99 & 1.03 & 0.99 & 1.01 & 0.016 \\
\hline 84 & $\mathrm{R}$ & Capillary & $62 \mathrm{R}$ & 1.92 & 1.98 & 2.54 & 2.19 & 2.30 & 2.63 & 2.26 & 0.288 \\
\hline 85 & $\mathrm{~L}$ & Capillary & 63L & 1.23 & 1.23 & 1.26 & 1.22 & 1.24 & 1.25 & 1.24 & 0.015 \\
\hline 86 & $\mathrm{R}$ & Packed & $64 \mathrm{R}$ & 1.27 & 1.65 & 1.26 & 1.30 & 1.42 & 1.55 & 1.41 & 0.162 \\
\hline
\end{tabular}


Table B5. Raw data of water yields for sample E (unit: $\mathrm{mg} / \mathrm{cig}$ ).

\begin{tabular}{|c|c|c|c|c|c|c|c|c|c|c|c|}
\hline \multirow{2}{*}{ No. } & \multirow{2}{*}{$\begin{array}{l}\text { Smoking } \\
\text { machine }\end{array}$} & \multirow{2}{*}{$\begin{array}{l}\text { GC column } \\
\text { type }\end{array}$} & \multirow{2}{*}{$\begin{array}{l}\text { Lab. } \\
\text { code }\end{array}$} & \multicolumn{6}{|c|}{ No. of run } & \multirow{2}{*}{ Mean } & \multirow{2}{*}{ SD } \\
\hline & & & & 1 & 2 & 3 & 4 & 5 & 6 & & \\
\hline 1 & $\mathrm{R}$ & Capillary & $01 R$ & 1.96 & 2.06 & 1.93 & 1.79 & 1.78 & 1.85 & 1.90 & 0.109 \\
\hline 2 & $\mathrm{R}$ & Capillary & $02 R$ & 2.40 & 2.19 & 2.10 & 2.09 & 2.48 & 2.09 & 2.23 & 0.172 \\
\hline 3 & $\mathrm{~L}$ & Packed & 03AL & 1.20 & 1.22 & 1.21 & 1.30 & 1.16 & 1.16 & 1.21 & 0.052 \\
\hline 4 & $\mathrm{R}$ & Packed & 03BR & 1.15 & 1.47 & 1.32 & 1.58 & 1.44 & 1.12 & 1.34 & 0.182 \\
\hline 5 & $\mathrm{~L}$ & Packed & 04L & 1.47 & 1.60 & 1.53 & 1.65 & 1.40 & 1.73 & 1.56 & 0.121 \\
\hline 6 & L & Packed & $05 \mathrm{~L}$ & 1.58 & 1.64 & 1.74 & 1.81 & 1.81 & 1.71 & 1.72 & 0.092 \\
\hline 7 & $\mathrm{~L}$ & Capillary & 06AL & 1.41 & 1.63 & 1.56 & 2.20 & 1.04 & 1.85 & 1.62 & 0.393 \\
\hline 8 & $\mathrm{~L}$ & Capillary & 06BL & 1.14 & 0.74 & 1.97 & 1.87 & 1.46 & 1.80 & 1.50 & 0.481 \\
\hline 9 & $\mathrm{R}$ & Capillary & 07AR & 2.27 & 2.29 & 1.92 & 2.19 & 2.18 & 2.14 & 2.16 & 0.132 \\
\hline 10 & $\mathrm{R}$ & Capillary & 07BR & 2.16 & 2.16 & 2.18 & 2.20 & 2.12 & 2.21 & 2.17 & 0.033 \\
\hline 11 & $\mathrm{~L}$ & Capillary & $07 \mathrm{CL}$ & 1.48 & 1.46 & 1.43 & 1.41 & 1.45 & 1.34 & 1.43 & 0.050 \\
\hline 12 & $\mathrm{R}$ & Capillary & 08R & 2.03 & 2.11 & 2.04 & 1.94 & 1.78 & 1.93 & 1.97 & 0.115 \\
\hline 13 & $\mathrm{R}$ & Capillary & 09R & 1.99 & 1.97 & 1.91 & 1.84 & 1.93 & 1.75 & 1.90 & 0.090 \\
\hline 14 & $\mathrm{R}$ & Capillary & $10 \mathrm{R}$ & 2.20 & 2.19 & 2.23 & 2.13 & 2.07 & 2.02 & 2.14 & 0.080 \\
\hline 15 & $\mathrm{~L}$ & Capillary & $11 \mathrm{~L}$ & 1.32 & 1.28 & 1.36 & 1.26 & 1.24 & 1.44 & 1.32 & 0.074 \\
\hline 16 & $\mathrm{R}$ & Packed & $12 \mathrm{R}$ & 2.08 & 2.32 & 2.37 & 2.10 & 2.09 & 2.15 & 2.19 & 0.126 \\
\hline 17 & $\mathrm{R}$ & Capillary & $13 A R$ & 1.69 & 1.53 & 1.48 & 1.42 & 1.60 & 1.38 & 1.52 & 0.115 \\
\hline 18 & $\mathrm{R}$ & Capillary & 13BR & 1.80 & 1.65 & 1.69 & 1.36 & 1.81 & 1.78 & 1.68 & 0.170 \\
\hline 19 & $\mathrm{R}$ & Packed & 14R & 2.04 & 1.76 & 1.90 & 1.90 & 1.84 & 1.96 & 1.90 & 0.096 \\
\hline 20 & $\mathrm{R}$ & Capillary & 15AR & 1.98 & 1.97 & 1.83 & 1.88 & 1.97 & 1.86 & 1.92 & 0.066 \\
\hline 21 & $\mathrm{~L}$ & Capillary & $15 B L$ & 1.41 & 1.85 & 1.73 & 1.46 & 1.33 & 1.36 & 1.52 & 0.215 \\
\hline 22 & $\mathrm{R}$ & Packed & $16 \mathrm{R}$ & 1.58 & 1.73 & 1.51 & 1.88 & 1.64 & 1.85 & 1.70 & 0.148 \\
\hline 23 & $\mathrm{R}$ & Packed & 17AR & 1.76 & 1.84 & 1.87 & 1.63 & 1.96 & 1.85 & 1.82 & 0.112 \\
\hline 24 & $\mathrm{~L}$ & Packed & 17BL & 1.20 & 1.41 & 1.31 & 1.36 & 1.33 & 1.25 & 1.31 & 0.076 \\
\hline 25 & $\mathrm{R}$ & Capillary & 18AR & 1.72 & 1.68 & 1.71 & 1.64 & 1.96 & 1.97 & 1.78 & 0.145 \\
\hline 26 & $\mathrm{~L}$ & Capillary & 18BL & 1.32 & 1.77 & 1.30 & 1.17 & 1.41 & 1.37 & 1.39 & 0.203 \\
\hline 27 & $\mathrm{~L}$ & Capillary & $19 A L$ & 1.48 & 1.60 & 1.59 & 1.71 & 1.71 & 1.67 & 1.63 & 0.089 \\
\hline 28 & $\mathrm{R}$ & Capillary & 19BR & 1.92 & 2.05 & 2.08 & 2.01 & 2.11 & 2.04 & 2.03 & 0.066 \\
\hline 29 & $\mathrm{~L}$ & Capillary & $19 C L$ & 1.76 & 1.59 & 1.76 & 1.61 & 1.88 & 1.80 & 1.73 & 0.112 \\
\hline 30 & $\mathrm{R}$ & Capillary & 19DR & 1.83 & 1.82 & 1.85 & 1.76 & 1.83 & 1.83 & 1.82 & 0.033 \\
\hline 31 & $\mathrm{~L}$ & Packed & 19EL & 1.49 & 1.49 & 1.45 & 1.40 & 1.41 & 1.42 & 1.44 & 0.040 \\
\hline 32 & L & Packed & $20 \mathrm{~L}$ & 1.60 & 1.67 & 1.67 & 1.66 & 1.57 & 1.55 & 1.62 & 0.054 \\
\hline 33 & $\mathrm{~L}$ & Capillary & $21 \mathrm{~L}$ & 1.76 & 1.85 & 1.86 & 1.86 & 1.85 & 1.85 & 1.84 & 0.039 \\
\hline 34 & $\mathrm{R}$ & Capillary & $22 \mathrm{R}$ & 2.07 & 1.89 & 2.10 & 2.02 & 2.18 & 2.12 & 2.06 & 0.101 \\
\hline 35 & $\mathrm{R}$ & Capillary & $23 R$ & 1.88 & 1.83 & 1.80 & 1.74 & 1.74 & 1.78 & 1.80 & 0.052 \\
\hline 36 & $\mathrm{R}$ & Capillary & $24 \mathrm{AR}$ & 1.66 & 1.89 & 1.84 & 1.79 & 1.70 & 1.83 & 1.79 & 0.088 \\
\hline 37 & $\mathrm{~L}$ & Capillary & $24 B L$ & 1.64 & 1.67 & 1.74 & 1.63 & 1.59 & 1.66 & 1.66 & 0.050 \\
\hline 38 & $\mathrm{R}$ & Packed & $25 R$ & 2.13 & 2.44 & 2.37 & 2.34 & 1.91 & 2.03 & 2.20 & 0.213 \\
\hline 39 & $\mathrm{R}$ & Capillary & 26AR & 2.12 & 1.96 & 2.24 & 2.33 & 2.03 & 2.07 & 2.13 & 0.137 \\
\hline 40 & $\mathrm{R}$ & Capillary & 26BR & 2.28 & 2.29 & 2.32 & 2.34 & 2.48 & 2.28 & 2.33 & 0.077 \\
\hline 41 & $\mathrm{~L}$ & Capillary & $27 \mathrm{~L}$ & 1.46 & 1.48 & 1.30 & 1.22 & 1.37 & 1.25 & 1.35 & 0.108 \\
\hline 42 & $\mathrm{~L}$ & Packed & $28 \mathrm{~L}$ & 1.67 & 2.15 & 1.95 & 1.84 & 1.86 & 1.75 & 1.87 & 0.167 \\
\hline 43 & $\mathrm{~L}$ & Packed & $29 \mathrm{~L}$ & 1.22 & 1.62 & 1.64 & 1.68 & 1.59 & 1.87 & 1.60 & 0.212 \\
\hline 44 & $\mathrm{R}$ & Packed & $30 \mathrm{R}$ & 2.17 & 2.16 & 2.13 & 1.94 & 2.21 & 2.01 & 2.10 & 0.105 \\
\hline 45 & $\mathrm{~L}$ & Packed & 31L & 1.33 & 1.72 & 1.88 & 1.30 & 1.38 & 1.59 & 1.53 & 0.236 \\
\hline 46 & $\mathrm{R}$ & Capillary & $32 \mathrm{AR}$ & 1.99 & 1.81 & 1.80 & 1.94 & 1.92 & 1.84 & 1.88 & 0.075 \\
\hline 47 & $\mathrm{R}$ & Capillary & 32BR & 2.11 & 1.94 & 2.16 & 1.86 & 1.91 & 1.72 & 1.95 & 0.161 \\
\hline 48 & $\mathrm{R}$ & Capillary & $33 \mathrm{R}$ & 1.71 & 1.69 & 1.56 & 1.55 & 1.55 & 1.41 & 1.58 & 0.110 \\
\hline 49 & $\mathrm{R}$ & Packed & $34 \mathrm{R}$ & 2.97 & 2.83 & 2.55 & 2.62 & 2.07 & 2.36 & 2.57 & 0.321 \\
\hline 50 & $\mathrm{~L}$ & Packed & $35 \mathrm{~L}$ & 2.20 & 2.31 & 2.50 & 1.98 & 2.35 & 1.94 & 2.21 & 0.219 \\
\hline 51 & $\mathrm{R}$ & Capillary & 36AR & 2.25 & 2.22 & 2.38 & 2.29 & 2.35 & 2.28 & 2.30 & 0.060 \\
\hline 52 & $\mathrm{R}$ & Capillary & 36BR & 2.44 & 2.49 & 2.40 & 2.45 & 2.47 & 2.35 & 2.43 & 0.051 \\
\hline 53 & $\mathrm{R}$ & Capillary & $37 A R$ & 1.96 & 1.50 & 1.56 & 1.39 & 2.12 & 2.18 & 1.78 & 0.341 \\
\hline 54 & $\mathrm{~L}$ & Capillary & 37BL & 1.53 & 1.77 & 1.84 & 1.55 & 1.64 & 1.89 & 1.70 & 0.152 \\
\hline 55 & $\mathrm{R}$ & Packed & $38 \mathrm{R}$ & 1.78 & 1.84 & 1.94 & 1.85 & 1.96 & 1.94 & 1.88 & 0.073 \\
\hline 56 & $\mathrm{R}$ & Packed & $39 R$ & 2.06 & 1.96 & 2.32 & 2.18 & 2.50 & 1.02 & 2.01 & 0.518 \\
\hline
\end{tabular}


Table B5. Continued.

\begin{tabular}{|c|c|c|c|c|c|c|c|c|c|c|c|}
\hline \multirow{2}{*}{ No. } & \multirow{2}{*}{$\begin{array}{l}\text { Smoking } \\
\text { machine }\end{array}$} & \multirow{2}{*}{$\begin{array}{c}\text { GC column } \\
\text { type }\end{array}$} & \multirow{2}{*}{$\begin{array}{l}\text { Lab. } \\
\text { code }\end{array}$} & \multicolumn{6}{|c|}{ No. of run } & \multirow{2}{*}{ Mean } & \multirow{2}{*}{$\mathrm{SD}$} \\
\hline & & & & 1 & 2 & 3 & 4 & 5 & 6 & & \\
\hline 57 & $\mathrm{R}$ & Packed & $40 \mathrm{R}$ & 2.47 & 2.52 & 2.75 & 2.54 & 2.98 & 2.92 & 2.70 & 0.219 \\
\hline 58 & $\mathrm{R}$ & Capillary & $41 \mathrm{R}$ & 1.90 & 1.82 & 1.79 & 1.58 & 1.80 & 1.80 & 1.78 & 0.106 \\
\hline 59 & $\mathrm{~L}$ & Capillary & $42 \mathrm{~L}$ & 1.44 & 1.43 & 1.68 & 1.55 & 1.60 & 1.44 & 1.52 & 0.104 \\
\hline 60 & $\mathrm{~L}$ & Packed & $43 \mathrm{AL}$ & 1.86 & 1.55 & 1.46 & 1.62 & 1.60 & 1.69 & 1.63 & 0.136 \\
\hline 61 & $\mathrm{~L}$ & Packed & $43 B L$ & 1.55 & 1.61 & 1.46 & 1.59 & 1.65 & 1.63 & 1.58 & 0.069 \\
\hline 62 & $\mathrm{~L}$ & Capillary & $44 \mathrm{AL}$ & 1.60 & 1.66 & 1.56 & 1.58 & 1.91 & 1.64 & 1.66 & 0.129 \\
\hline 63 & $\mathrm{~L}$ & Capillary & 44BL & 1.71 & 1.43 & 1.49 & 1.45 & 1.82 & 1.60 & 1.58 & 0.156 \\
\hline 64 & $\mathrm{R}$ & Packed & $45 \mathrm{R}$ & 1.74 & 1.68 & 1.80 & 1.75 & 1.69 & 1.59 & 1.71 & 0.073 \\
\hline 65 & $\mathrm{~L}$ & Packed & $46 \mathrm{~L}$ & 0.89 & 0.97 & 1.05 & 0.96 & 1.05 & 1.11 & 1.01 & 0.079 \\
\hline 66 & $\mathrm{~L}$ & Packed & $47 \mathrm{~L}$ & 1.85 & 1.88 & 1.53 & 2.05 & 1.50 & 1.40 & 1.70 & 0.259 \\
\hline 67 & $\mathrm{~L}$ & Capillary & $48 \mathrm{~L}$ & 1.80 & 1.78 & 1.77 & 1.77 & 1.73 & 1.81 & 1.78 & 0.028 \\
\hline 68 & $\mathrm{R}$ & Packed & 49R & 1.90 & 1.95 & 1.91 & 1.79 & 2.18 & 1.91 & 1.94 & 0.129 \\
\hline 69 & $\mathrm{R}$ & Packed & 50AR & 1.77 & 1.77 & 2.02 & 1.91 & 1.79 & 1.72 & 1.83 & 0.113 \\
\hline 70 & $\mathrm{R}$ & Packed & 50BR & 1.82 & 1.89 & 1.91 & 1.82 & 1.87 & 1.79 & 1.85 & 0.047 \\
\hline 71 & $\mathrm{~L}$ & Packed & $50 \mathrm{CL}$ & 1.39 & 1.52 & 1.45 & 1.68 & 1.42 & 1.31 & 1.46 & 0.127 \\
\hline 72 & $\mathrm{R}$ & Capillary & 51R & 1.94 & 2.44 & 2.21 & 2.16 & 2.22 & 2.15 & 2.19 & 0.160 \\
\hline 73 & $\mathrm{R}$ & Capillary & $52 \mathrm{R}$ & 2.15 & 1.93 & 2.11 & 2.24 & 2.13 & 2.51 & 2.18 & 0.192 \\
\hline 74 & $\mathrm{~L}$ & Packed & $53 \mathrm{~L}$ & 1.71 & 1.73 & 1.63 & 1.74 & 1.64 & 1.67 & 1.69 & 0.047 \\
\hline 75 & $\mathrm{R}$ & Capillary & 54R & 1.92 & 1.74 & 1.87 & 1.88 & 1.86 & 1.80 & 1.85 & 0.064 \\
\hline 76 & $\mathrm{R}$ & unknown & 55R & 2.06 & 2.25 & 2.06 & 1.69 & 1.88 & 1.88 & 1.97 & 0.195 \\
\hline 77 & $\mathrm{~L}$ & Packed & $56 \mathrm{~L}$ & 2.14 & 4.08 & 6.49 & 4.21 & 4.49 & 4.59 & 4.33 & 1.388 \\
\hline 78 & $\mathrm{R}$ & Packed & 57R & 2.28 & 2.19 & 2.39 & 2.24 & 2.32 & 2.15 & 2.26 & 0.088 \\
\hline 79 & $\mathrm{~L}$ & Packed & $58 \mathrm{~L}$ & 1.45 & 1.40 & 1.37 & 1.54 & 1.68 & 1.53 & 1.50 & 0.113 \\
\hline 80 & $\mathrm{~L}$ & Packed & $59 \mathrm{~L}$ & 2.29 & 3.61 & 3.99 & 2.46 & 4.06 & 3.23 & 3.27 & 0.758 \\
\hline 81 & $\mathrm{R}$ & Packed & 60AR & 2.21 & 2.05 & 2.21 & 1.98 & 2.28 & 2.29 & 2.17 & 0.127 \\
\hline 82 & $\mathrm{~L}$ & Packed & $60 \mathrm{BL}$ & 2.18 & 2.19 & 2.68 & 2.74 & 2.32 & 2.35 & 2.41 & 0.243 \\
\hline 83 & $\mathrm{R}$ & Packed & $61 \mathrm{R}$ & 1.90 & 1.91 & 1.89 & 1.88 & 1.91 & 1.90 & 1.90 & 0.012 \\
\hline 84 & $\mathrm{R}$ & Capillary & $62 R$ & 2.09 & 1.99 & 2.73 & 2.75 & 2.18 & 2.34 & 2.35 & 0.326 \\
\hline 85 & $\mathrm{~L}$ & Capillary & $63 \mathrm{~L}$ & 1.75 & 1.66 & 1.65 & 1.73 & 1.67 & 1.67 & 1.69 & 0.041 \\
\hline 86 & $\mathrm{R}$ & Packed & $64 \mathrm{R}$ & 1.56 & 1.34 & 1.32 & 1.23 & 1.42 & 1.69 & 1.43 & 0.170 \\
\hline
\end{tabular}

